\title{
THE EMERGENCE OF A NEW APPROACH TO THE PUBLIC SECTOR: THE NEW PUBLIC MANAGEMENT
}

\author{
Uğur ÖMÜRGÖNÜLŞEN*
}

\section{Introduction}

It is more than two decades since the first "Oil-Price Shock" gave rise to serious economic difficulties in Westem economies, and it is almost two decades since the first conservative government in a Western country came to power on the basis of ideology which repudiated the "post-war consensus" formed around "Keynesian mixed economy" and the "welfare state". The public sector has become topical because of profound changes in its economic and ideological environment during the 1980s and 1990s. In Western countries the renewed interest of governments and academic circles in this field results from a number of factors interlinked in a variety of ways. Prominent among them are: the economic crisis of the 1970s; the changes in ideological perceptions about the role of government in social and economic life and then the collapse of post-war consensus based on Keynesian economic management and the institutional/universal welfare state; the rise in demand for social services and fiscal crisis of the welfare state; and the search for the most suitable institutions and techniques for promoting economy, efficiency, and effectiveness in the provision of public services in the face of oversized, overbureaucratic, and coercive administrative structures.

The debate of the 1980s was about redefining the boundaries between the public and private sectors in favour of the private sector since the developed world faced the reality of financial crisis duc to the detcrioration of economic performance and increased demand on public services. The opposition to the over-expansion of the public sector has gained ground since the late 1970s and then the "withdrawal of government" has become the official policy of conservative governments in Western Europe and North America. This ideological climate has soon spread to other countries and has affected even some social democrat governments as in the cases of Australia and New Zealand. Governments have responded to the phenomenon of "big government" by taking some measures to cutback public expenditures and staff in order to reduce taxes; to privatise

* Research Assistant in the Department of Public Administration at Hacettepe University 
state owned enterprises and to deregulate private economic enterprises with their belief in the $;$ "superiority of market" in efficient allocation of resources; and to launch VFM auditing/efficiency scrutiny for savings. The debate of the 1990s is no longer the same though it is linked to the previous debate. Even if the public sector is downsized, whatever remained in the public sector should be betuer managed. Thus, the problem of efficient use of resources in this smaller public sector has still been waiting to resolve. In other words, resources must be used efficiently to provide public services, at least, at the same level and with the same quality as in the past since resources allocated to the public sector are now more scarce. This reality has forced the governments to search a new system of ideas, structures, techniques and practices which is appropriate to this relatively smaller public sector. Under these circumstances the size, values, structure, and functioning of national public sectors have been affected deeply all over the world. A cost-conscious, debureaucratised, market-oriented and customer-favoured public service has jbecome an "ideal" system to build. The provision of public services by more able managers and more flexible structures/processes in accordance with both efficiency criteria and wishes of consumers has become the central theme with the effect of the public management approach and, in particular, its specific version, the new public management (NPM) approach.

In brief, the 1980s and 1990s have witnessed a transformation in the management of the public sector in many advanced countries. The rigid, hierarchical, bureaucratic form of public administration is changing to a flexible, market-based form of public management. This is not simply a matter of change in management style, but it is often considered as a "paradign shift" from the traditional public administration approach, which was dominant in the public sector for most of the century, to the public management (and to NPM). The traditional approach has been severely criticised on theoretical and practical grounds. Both this approach and the discipline of public administration have suffered from a serious decline in their prestiges. Therefore, NPM as a new "paradigm" poses a direct challenge to both the traditional public administration approach and the distinctive nature, culture, and fundamental principles of the discipline of public administration.

In this article, the following points will be discussed in order to understand the true nature of the emergence of NPM as an alternative approach to the study and practice of the public sector:

(i) Paradigm shift in the public sector?: The critique of fundamental features of the traditional public administration approach and a serious decline in the prestige of the disćipline of public administration;

(ii) Changes in the perceptions and priorities in the public sector: economic and political/ideological changes gave rise to NPM (i.e. NPM as a megatrend and relationships betwcen the NPM approach and New Right ideology);

(iii) As a conclusion, the strength of the NPM approach in creating a new consensus and the irreversibility of recent public sector reforms.

I. Paradigm Shift in the Public Sector?: Critique of Traditional Public Administration Approach and a Serious Decline in the Prestige of the Discipline of Public Administration 
There has been a profusion of approaches and then confusion in describing the study and practice of the public sector in the second half of the twentieth century. In the 1950s and early 1960s, the focus in many Western countries was upon institutional reform and this was reflected in the concern of academics with changing settings, structures and staffing in the public sector. The traditional public administration approach of that era was a mixture of description, comparisons with other Anglo-American and Western European countries and prescriptions for reform in the machinery and formal procedures of government. This approach was defined but also delimited by its parent disciplines of political science, organisation theory and-in particular in continental European context-administrative law.

In the 1960s and early 1970s many academics were influenced by the policy analysis literature which was developed mainly in the United States. This was coincided with the planning mood in some Western European governments and the development of think-tanks and rationalist exercises in strategic policy-making. Public organisation was considered as an integral to the political process since bureaucrats play an important role in formulating public policies and its implementation. This was the denial of the traditional politics/administration dichotomy. Thus, the traditional public administration approach was to some extent overtaken by the more interdisciplinary public policy approach.

Until two decades ago government was accepted as a principal means to solve problems. Traditional public administration and public policy approaches flourished in this ideological atmosphere. Since the mid-1970s, government has become identified by many as the problem in the face of serious financial crisis, and then the practical concern of governments, almost all over the world, has been with rolling-back the frontiers of government including the pursuit of efficiency in government through more "businesslike" values, techniques and practices. Thus, management function has become more critical to the current problems rather than administration and policy-making (1). Within this context, a management approach to the public sector, instead of traditional public administration, has been developed over the last two decades (see Bozeman, 1993; Bozeman and Strausman, 1984; Perry and Kraemer, 1983; Rainey, 1991; Garson and Overman, 1983; Lynn, 1996). The term public management has been offered as a rival to, a substitute for, or sometimes a synonym of public administration (Bozeman, 1993: xiii). Public management is actually different from the previous approaches to the public sector. During the 1980s and 1990s it has been derived from different positive influences of public administration (normative procedures), public policy (policymaking) and private sector management (strategy). It has also taken into consideration the weaknesses of each approach. Traditional public administration is highly discursive and skill poor (Allison, 1979; Perry and Kraemer, 1983). Public policy gives too litule atention to management function (Beyer, Stevens and Trice, 1983). Generic management and private sector management are inattentive to essential features of the public sector (Rainey, 1990). Public management approach in general and NPM in particular seem to replace traditional public administration and public policy approaches which have hitherto dominated academic thinking and the practice of public affairs (see Perry and Kraemer, 1983 and Gunn, 1987; Bozeman, 1993; Hughes, 1994).

Within general public management approach, vitality and diversity in theoretical standpoints, empirical research and practices which mainly stem from the effects of its 
different strands (i.e. economic, managerial, and newly developing normative publicness strands) can easily be traced (2). Especially, a new and distinctive model or approach of management for the public sector within this general public management framework has been on the agenda since the early 1980s. This new approach has actually several incarnations. "Public management" (Perry and Kraemer, 1983), "supply-side maniagement" (Carroll, Fritschler and Smith, 1985), "managerialism" (Pollitt, 1993-first edition in 1990), "new public management" (see Hood, 1990b, 1991; Pollitt, 1993; and Mascarenhas, 1990), "entrepreneurial government" (Osborne and Gaebler, 1992) are the mośt well-known versions of this general public management approach. In our opinion, the best heading for the rexent changes in the study and practice of the public sector is the new public management (NPM). We believe that NPM is a new approach to the study and practice of the public sector and its position between traditional public administration approach and private (business) management approach is very special.

NPM is a convenient shortname for an approach to the public sector. It contains a set of values, norms, techniques and practices conceming the management in the public sector. With NPM " ... higher priority is given to the "management" of people, resources and programmes compared to the "administration" of activities, procedures and regulations» (Aucoin, 1988: 152). Implicit in the shift towards NPM in the public sector has been the assumption that traditional administrative function should be superceded by a more economistic and managerialistic function.

NPM docs not have a single theorctical origin. Therefore, NPM's origin can be interpreted as a "marriage of two different streams of ideas" which mainly come from the fields of economics and management. There is a growing consensus on the theoretical bases of NPM in the literature of "economics" and "management" (see Hood, 1991: 5; alsó see Hood, 1989; Aucoin, 1990; OECD, 1991: 11; Hughes, 1994: 74-77). Hood specified the effects of economics and management on the emergence of NPM by naming more particular strands of them: the new institutional economics (i.e. public choice, principal-agent, transaction-costs and property rights theories) and the managerialism (1991: 5; for a similar approach, sec Aucoin, 1990). We can also distinguish two different strands of managerialism: "neo-Taylorian managerialism" (see Pollitt, 1993) and "new wave of management" (variously called new managerialism, post-burcaucratic management, the 'excellence' approach, the new human resource management and even entrepreneurial government) (see Peters and Waterman, 1982; Peters and Austin, 1985; Peters, 1989; Wood, 1989; Osborne and Gaebler, 1992). Managerialism is only one dimension of NPM in addition to economic one. With several exceptions (e.g. Jackson, 1990 and 1994; Aucoin, 1990; Hood, 1991; Rhodes, 1991; Dunleavy and Hood, 1994; and Dunleavy, 1994), authors have mainly dealt with the "managcrial' side of NPM whereas the "economic" side of NPM is as important as its managerial one. Actually all managerial developments have centred around efficiency concept which is the crux of the matter since the early 1980s. NPM is, therefore, different from "entrepreneurial government" approach with its emphasis on economics. It also marks a shift from the earlier American usage of public management (or "old" public management) which sees it as a technical sub-field of public administration.

Whether the sources of NPM are fully compatible remains to be discussed. This is, to some extent, because NPM does not have a single theoretical origin. Each strand of NPM has its own distinctive characteristics and therefore they might contradict. There is a potential incompatibility of the new institutional economics (public choice) which 
provides "governance level" and managerialism which provides "managerial level" of administrative reform guided by NPM (see Scott and Gorringe, 1989: 81-82; Aucoin, 1990; Campbell, 1995: 484-485). Furthermore, there are some intemal tensions within each strands (see Pollitt, 1993: Chp. 5). However, these tensions cannot falsify the argument that NPM can be considered as a paradigm shift. In our opinion Aucoin's (1988 and 1990) efforts on this subject and some other recent academic work (e.g. Hoggett, 1991, 1996; Holmes and Shand, 1995) combined with practical developments in the reform programmes suggest that these tensions can be resolved. After a "tight" political control is established, a "selective" centralisation/decentralisation, cooraination/deregulation and control/delegation in accordance with the "tight-loose" principle (see Peters and Waterman, 1982) is likely to be a more practical solution to the current problems of the public sector (3).

\section{A. Paradigm Shift in the Public Sector?}

As we mentioned above, the traditional theories and practices of public administration are under attack politically and intellectually from both politicians and experts who undertake administrative and financial reform agendas of many OECD countries. Further, in many countries there has been much talk of "administrative revolutions" or "paradigm shifts" in the study and practice of the public sector as a worldwide phenomenon (Gray and Jenkins, 1995: 75-76) (4).

The idea of "paradigm" is borrowed from the work of the philosopher of sciences, Thomas Kuhn $(1964,1970)$. It relates to the evolution of scientific disciplines. When a commonly held value consensus breaks down, it is replaced by a new and generally externally constructed set of values and assumptions. The revolution, therefore, brings new values, new agendas, and often new people redefining the area which is driven by the new paradigm. How far this analysis can fairly be transferred to social sciences and to the study and practice of public administration is highly controversial (5) but another matter. Nevertheless, academic discourse on different forms of paradigmatic crisis and shifts has been a common practice in social sciences (see Haque, 1996a). Public administration could not avoid this trend either (Saylan, 1996). Many public administration scholars from different ideological standpoints defend the value of paradigms as a means of resolving the "crisis of identity" in public administration and argue that public administration cannot progress without an appropriate paradigm (sce Ostrom, 1974-first edition in 1973; Bellone, 1980; Waldo, 1980; Harmon, 1981). As a matter of fact, numerous claims of a paradigm shift have been made since the mid-1970s. For example, Henry's (1975) four paradigms characterise the evolution of public administration in the twenticth century, in particular in the American setting: "politics/administration dichotomy" (1900-1926); "the principles of administration" (1927-1937); "public administration as political science" (1950-1970); and "public administration as administrative science" (1956-1970). The last paradigm (the so-called "generic management" approach) competed with the political science paradigm in the 1970s. Pcrry and Kracmer (1983), influenced heavily by Henry's paradigms, proposed "public management" as an emerging and integrative paradigm of the post-1970s.

Recently, new claims of paradigm shift have been put forward: for example, the move to "managerialism" (Pollitt, 1993); the move to a "post-bureaucratic" paradigm (Aucoin, 1990; Barzclay with Armanjani, 1992; Kernaghan, 1993); or the move to "market-based public administration" (Lan and Rosenbloom, 1992) or to "entrepreneurial 
government" (Osbome and Gaebler, 1992). Many authors are actually saying similar things with different catchwords: Pinkerton's "new paradigm"; Hammer's "process reengineering"; Johnston's "beyond bureaucracy" (see Goodsell, 1994: 178). There has also been extensive discussion of the shifting values that underly the transition from traditional public administration to thenew public management (Hood, 1990b, 1991; Pollitt; 1993; Mascarenhas, 1990; Rhodes, 1991; Dunleavy and Hood, 1994; Hughes, 1994 ) or to the "new public sector management" (Jackson, 1994). At least, quite a few authors have considered "public management" as a new and competing approach which has been developed in order to study public sector (e.g. Gunn, 1987, 1988).

Does the emergence of NPM represent the development of a "new paradigm"? Undoubtedly its rhetoric suggests so. It is known that NPM represents a hostility to the values of traditional public administration. The consequence is the redefinition, isolation or relocation of the areas of the study of public administration and the launching of a comprehensive reform agencla in the public sector. Therefore, some authors mentioned above consider this shift as an "emerging paradigm". For more critical eyes, how far NPM justifies a "new paradigm" remains an open question. This shift naturally gives rise to the question, "what is new here?". Some aspects of NPM might be new in comparison with the traditional public administration. Thus, Eliassen and Kooiman say: "we feel a change is in the air» (1987: 16) in this respect. But, what is new in terms of general public management? Lynn (1996) explains in his review of the literature on public' management that there is absolutely nothing new about the use of marketlike mechanisms, privatisation, decentralisation, an emphasis on quality, or even a customer orientation. At this point Thompson asks: "Does this mean that the "new" in the New Public Management is to he found, therefore, entirely in modifiers like "bold" or "inten'sified"?». And he answers himself thus « [p]erhaps it is, but probably not» (1997: 166).

The best point to begin to answer these questions is with public management because a New Public Management logically implies an old public management which was developed in the 1970s and 1980s. Although it is sometimes argued that public management is only a renewed interest in long-standing isșues of the public sector exposed by the traditional approach, with an emphasis on contemporary applications (see Allison, 1979; Rourke, 1984; Ingraham and Ban, 1986; Lynn, 1987; Rainey, 1990), there are some significant differences between public management and traditional public administration approaches. According to Garson and Overman (1983), these involve: a strong philosophical link with management studies in lieu of close ties to political science. Therefore, there is a focus on the organisation itself rather than a focus on laws, institutions, and political-bureaucratic processes, a focus on management values and functions rather than social and political values and conflicts between bureaucracy and democracy, and a focus on middle-level managers rather than political (or policy) elites. Thus, a more generic tendency to minimise the differences between the public and private sector's in lieu of accentuating them has been adopted.

As a matter of fact, the proponents of the NPM approach have not focused on social and political values and institutions either, although all have given more or less attention to the political feasibility of reform. Instead, they have tended to focus on managerial values and mechanisms by establishing close ties to generic and business management studies For example, business gurus are all cited positively and far more frequently than are the giants of public administration. As Thompson (1997) argues, 
NPM has a lot in common with the old public management, but there are also some important differences which make NPM a different version of general management approach. It is less interested in organisations per se than in institutional design and choice. It seeks to privatise public services that can be privatised; to contract in or out support services; to establish bottom-line bureaus governed by contracts as appropriate; to take advantage of competition where possible; and to restrict direct bureaucratic provision to core public services. As is seen, in addition to strong links with management studies, NPM has close ties to economics, especially the economics of organisations and public choice. This distinctive feature of NPM is also a result of its relation with New Right ideology (see Pollitt, 1993 and 1996; Mascarenhas, 1993; Gray and Jenkins, 1995; Rhodes et al., 1995; Farmham and Horton, 1996b: 42).

Although some of its values and practices are not new, they are reinterpreted or reformulated under the new circumstances. For example, control and efficiency concerns of Taylorism have become popular again under the label of "nco-Taylorism" (see Pollitt, 1993). Also the traditional politics/administration dichotomy has come to the agenda again with a new interpretation (6). With value for money analysis, economic concerns are renewed. However, NPM is not one in which old truths can be reasserted. It is one in which "new principles" have to be developed. Government must face the challenge of innovation rather than rely on imitation. Improving public management is not just a matter of catching-up with what is already being done in business; it also involves breaking new ground (see Metcalfe and Richards, 1990: 35).

Some authors consider NPM as a "revolution", or a "paradigm shift", but others see it as "explorations" towards a new paradigm or a "competing vision" (sce Kooiman and Eliassen, 1987; Gray and Jenkins, 1995). It seems to us it will lead to another long lasting theoretical debate in the field. Although the terms used by these authors are different and these various terms reflect, to some extent, differing views of what is occuring, they do have common points to indicate the same phenomenon: improving management in the public sector by replacing traditional public administration with a new approach. Whether these developments are so great as to call them a "revolution" or "paradigm shift" is subject to endless debate, and especially is a matter for empiricial investigation, but one thing is certain. The nature of conducting public affairs in the public sector and the structure, practices and culture of the public sector are changing significantly. Despite its highly rhetorical and ritualistic aspect, nobody can deny and ignore the scope and effect of the recent changes in the public sector. These changes, guided by NPM, have already had substantial impacts on the relationships between government, bureaucracy and citizens/customers. Moreover, all these changes are legitimised by using the "government failure" argument and severe critique of the traditional approach and the discipline of public administration.

\section{B. The Critique of the Traditional Public Administration Approach}

Two main competing models or approaches can be distinguished in both academic studies and practices in the public sector for approximately last two decades. The first one is the traditional public administration approach. The "public" aspect and "bureaucratic/legal process" of public sector are highlighted by this approach and thus it is oriented towards public philosophy (public law and political science). The traditional public administration approach, the longest standing theoretical framework to the study 
of public sector, is now being challenged and partially supplanted by NPM. Almost a century after its adoption, it cannot be expected that traditional approach will disappear or will be replaced completely by another approach overnight. As a matter of fact, some of its fundamental elements still exist. However, they are now considered old-fashioned and no longer relevant to the needs of a rapidly changing society sincethe focus of govemments has shifted from legal/formal and rigid structures, procedures and safeguards to flexible structures, and results (Hughes, 1994: 24). Within this framework, it would not be a mistake to say that bureaucratic and legal rules and even the relationships between the administration and law are the first things to be questioned. Since economic/managerial rationality has been rapidly replacing legal rationality, administrative law and its basic concepts, institutions and principles, in particular in the continental European countrics, have been reconsidcred. Even in those countries which have a long tradition of administrative law, there is a tendecy from the application of administrative law to that of private law, from the application of administrative justice to that of general jurisdiction. The performance of government is no longer assessed by the only' criterion of legality but by some tangible results. Therefore, the government is looking for a new rationality and the internal structures and procedures of government are being radically altered (Tan, 1988, 1995).

The theoretical foundations of the traditional public administration approach derive from several sources: from Wilson came the "politics/administration dichotomy" in order to make public administration an independent discipline and to achieve political neutrality in the public services; from the Northcote-Trevelyan Report (in the U.K.) in 1854 and the Pendleton Act (the U.S. Civil Service Act) in 1883 came the "merit system" against the patronage system; from Weber came the "theory of bureaucracy"; from Taylor came "scientific management"(the one best way); and from classical writers such as Fayol, Gulick, and Urwick came "universal principles of administration". Thus, the discipline of public administration was established, in particular in the AngloAmerican world, on a "technical" base by Wilson, Weber and Taylor in order to separate it from political science. While politics/administration dichotomy was used to establish an independent discipline of public administration from political science, the demarcation line between public administration and private management has become blurred. Political neutrality guaranteed efficiency in administration, and efficiency concern legitimised political neutrality (see Bouckaert, 1990: 55). As administration was seen politically neutral and technical, there would be nothing unique about the operational methods used in the public sector. As a matter of fact, most of the major classical figures in this field claim that their theories and insights apply to most or all types of organisations (Raincy, 1991: 4-5; 16-18). As a result, a series of methods were imported from the private sector. The main concern of the traditional approach was, therefore, efficiency though the means to achicve this aim (e.g. monolithic structures, centralisation, uniformity, burcaucratic processes) were different from the means of today. In the continental Europe, the traditional approach had more normative aspects, despite the discipline of public administration struggled to have its independence from general public law.

Theorisation in this field began in the second-half of the nineteenth century and then became formalised in the first quarter of the twentieth century. The traditional model was! of course, modified to some extent in time by the effects of theoretical and ideological developments: For example, although the mechanisms set up against spoils system were totaly adopted and supported, the politics/administration dichotomy was 
denied by political science-oriented perspectives. Although bureaucratic structures were constructed in accordance with the principle of separation between politics and administration, this principle was widely regarded as a "myth" (Caiden, 1982: 82; Peters, 1989: 4). The attempt to be a "non-political" was also considered as a reluctance to recognise the distintive political nature and significance of the public service. Countless studies and commonsense observation by practitioners testify to the fact that ethical judgements by administrations intrude into the policy formation process at all levels. As a matter of fact, this myth has been called into question since the late 1940s (see Marx, 1946; Appleby, 1949; Gaus, 1950; Long, 1954; Shick, 1975) and then discredited to a great extent.

As Kingdom points out, if one accepts the unreality of the distinction between politics and administration, it becomes logically necessary to assert the actuality of the distinction between public and private administration because policy-making in the public sector profoundly differs from that in the private sector in terms of process, content, and ethical purpose (1986a: 3). Although its main bureaucratic characteristics were largely remained , the "public" aspects of the approach were asserted more often and loudly (i.e. more realist interpretation of the dichotomy of politics and administration on the base of political neutrality rather than a fictious separation between policy-making and administration functions (7); direct public service provision; public service professionalism; public service unionism; more humanistic employec relations) by the political science-oriented perspectives such as "new public administration" and "public policy", with the effect of social-democratic post-war consensus. Thus, the political nature of the traditional approach was emphasised in addition to its technical expertise. This is why the traditional approach draw some characteristic debates not only from the world of administrative/bureaucratic theories but also from political science. However, this kind of modification did not change the bureaucratic character of the approach but reinforced it due to increased direct service provision and public service professionalism. As a result, this modification has reinforced the criticisms against inefficiency stemming from uniform-centralist-bureaucratic classical principles instead of bringing a new solution to this acute problem of the public sector.

The traditional public administration approach was, without any doubt, a great improvement over previous administrative thoughts and practices, but the inadequacies of this approach are now apparent, in particular, in terms of efficiency concerns. Public administration was considered as a governmental application of generic administrative concepts and practices by many classical writers such as Wilson in order to gain public administration's independence from political science. However, their tools to achieve efficiency in government were very rigid and bureaucratic (see Hughes, 1994: 44-56). There are also some particular problems with Weberian model of burcaucracy which have been highlighted especially by public choice writers. The first problem is the Weberian model of bureaucratic behaviour. Weber considered, or at least he wanted, that bureaucrats automatically follow the rules to seek public interest whereas public choice writers consider individual bureaucrat as a rational man secking his self-interest (i.e. utilitymaximisation hypothesis) and clarify his role in "office politics". Therefore, they have developed strong arguments regarding bureaucrats as endogenous non-passive agents who have their own personal interests that will influence policy outcomes (Tullock, 1965; Downs, 1967; Niskanen, 1971; Jackson, 1982). The second problem is also one Weber did not foresee. This is the supposed technical superiority of bureaucracy that Weber saw as higher than through any other conceivable process. However, Weberian bureaucracy is 
no longer universally seen as a form of organisation which provides the maximum technical efficiency. It is strongly argued that it breeds timeserves not innovators, it encourages administrators to be risk-averse rather than risk-taking and to waste scarce resources instead of using them efficiently. Weber saw bureaucracy as the "ideal type" but bureaucracy is usually criticised for producing inertia, lack of initiative, red tape, mediocrity and inefficiency. Moreover, all these diseases thought to be endemic in public organisations (Crozier, 1964; Merton, 1968; Caiden, 1981).

,

There are newer theories of organisational structure and behaviour which argue that formal bureaucratic nodel is no longer particularly efficient or effective, when compared to more flexible forms of management. The traditional public administration approach was developed at a particular stage of industrialisation. It suited relatively small and stable public sector (Thompson, 1967; Mintzberg, 1979, 1983; Hood, 1990b; Hill, 1992). Despite some of its advantages (e.g. precision, continuity, stability, discipline, reliability), fixed and rigid procedures and orderly working patterns do not work when the environmeat is constantly changing (see Schön, 1983; Drucker, 1986; and Argyris, 1990). As a matter of fact, it «simply do[es] not function well in the rapidly changing, information-rich, knowledge - intensive society and economy of the 1990s» (Osbiome and Gaebler, 1992:12). It is now often argued that the traditional model was a great reform in its day, but its "golden age" has gone and the world has moved on(Hughes, 1994: 48, 56). What has previously been positively valued are now considered as costs rather than benefits. Therefore, it is argued that the public organisations should be designed according to "post-orthodox" principles which are derived from the new realities of the public sector (i.e. complexity, public-private sector interaction, technological change, limited resources for growth, diversity of workforce and clientele, individualism and personal responsibility, quality of life and environmentalism) (see Emmert, Crow and Shangraw, Jr., 1993). Traditional bureaucratic principles should be reconsidered (balancing the trade off between speed and mistake/abuse) and then used in accordance with the change in society (see Rhodes, 1991: 553-554; and Kelman, 1991).

Traditional public administration is now considered as one of the main sources of efficiency and effectiveness problems in public services with its monopolistic service production and provision, vague notion of public interest, overcentralist, overbureaucratic and coercive features. The traditional approach has an input-dominated structure. It is too obsessed with regulating processes and controlling inputs rather than concerning with results (Osborne and Gaebler, 1992: 14). Once an organisation set up it is assumed that establishing the hierarchy. the personnel system, and the like, would lead to satisfactory results by themselves. The efficiency and effectiveness of the tasks are the concern of someone else. Also, politicians may not have been capable of or willing to monitor performance. Newer theorits of organisation, however, recognise that formal bureaucracy has some strengths but that there are alternative structures possible (Vecchio, 1991). The private sector is moving away from formal burcaucratic structures towards decentralised and flexible structures. With the effect of this change, the focus of subsequent reforms in the public sector has also been to move away from a rigid and bureaucratised structure to a more fluid structure. While there may be a need for order and precision in management, there is now a greater need for speed, flexibility and results. However, changing the existing system into a one that is speedy, risk-taking, outputoriented, innovative and efficient requires a remarkable change in the public service culture. 
In brief, the 1980s and 1990s have witnessed a transformation in the economy and management of many advanced countries. Governments have implemented more or less similar economic and managerial strategies as a "universal panacea", to make their public sectors like corporate business (see Metcalfe and Richards, 1990; Boyle, 1992; Massey, 1993; Ormond, 1993; Sclf, 1993; Hughes, 1994; Savoie, 1994; Bouckaert and Halachmi, 1995; ILO, 1995; Johnston and Callender, 1997; Mascarenhas, 1993; Butler, 1994; also see OECD-PUMA publications and OECD Public Management Developments Surveys in those years). The statist, bureaucratic, paternalist, uniform and monolithic, centralist and hierarchical form of public administration is changing to a market-based (flexible, decentralist, innovative, and entrepreneurial) form of public management.

\section{Decline in the Prestige of Public Administration Discipline}

Recent changes mentioned above have challenged not only the values, structure and operation of the public sector but have shaken the pillars of the discipline of public administration. Public administration as a study and practice is usually considered as a rather "dull area" or "boring subject" linked to the sector that is seen as out of fashion (see Kingdom, 1990: 13; Chandler, 1991: 44). Even the tcrm "public administration" as a discipline and practice seems to be under threat, with terms like "public management" or "public sector management" being used increasingly instead (Grcenwood and Wilson, 1988: 349 and 1989: 15) (8). There has been a tendency that the discipline of public administration is repudiated and it is getting defined as public management. The evidence of this tendency of change can be understood from the recent modifications made in the name of institutions, academic courses, prestigious conferences, academic/official publications and in their locations and contents. The term "public administration" is disappearing fast due to the flurry of institutional renaming public administration courses to incorporate management in the title (e.g. courses in public sector management, public policy and management, public administration and management, and public management appeared on the scene) (see Hunt, 1990; Chandler, 1991; Midwinter, 1990; Gray and Jenkins, 1995: 82; Pollitt, 1996: 84-85). Meanwhile, the actual work done by public authorities is far more often called "management" (Hughes, 1994: 8). There has been a trend towards the use of words "management" and "manager" within the public sector. "Public administration" and "administrator" are clearly losing favour as a description of the work carried out. The term manager is becoming more common, where once administrator was used (Pollitt 1993: vii; Hughes, 1994: 6; see also Gray and Jenkins, 1995: 84; and Aucoin,1988: 153). A new class of managers are being created out of administrators and professionals (Hoggett, 1991: 254). Indeed, the overall process has produced a shift from management by professionals to professionalisation of management (Thompson and McHugh, 1995: 89).

Although there is a close link between ideological/economic transformation experienced in the public sector and the repudiation of the traditional public administration approach, this repudiation is also an inevitable result of the disarray (i.e. the assumed "identity crisis" or "intellectual crisis") (9) of the discipline of public administration in terms of its scope, subject matter, and research methodology (10). In other words, diversities and inadequacies in theoretical approaches, research topics and methodologies, research quality, education curricula; and the defensive attitudes of public administration scholars have also facilitated the repudiation of traditional public 
administration approach and the rise of NPM as an alternative approach or a new paradigm. Ostrom (1974) claims that we can anticipate a resolution of the intellectual crisis in public administration only if an alternative paradigm is available. The alternative paradigm is inherent in the work of contemporary political economists (mainly public choice writers). Thus NPM containing some public choice assumptions could be a new paradigm to overcome the identity crisis (11).

Public administration departments and scholars, in particular in the U.K., have become outsiders in the recent developments in the study and practice of the public sector (see Rhodes, 1991: 548, 550; Dunsire, 1995: 21) except a small minority (e.g. Dunsire and Hood, 1989; Dunleavy, 1991; alsso see ESRC's research initiative on Management in Government, 1985). New Rightist think-tanks, business people (e.g. contractors), some govermment organisations and practitioners (e.g. some central control agencies, audit commissions, specialised committees and high - level public officials-the élite ranks) and proféssionals (e.g. accountints and lawyers) and management consultants and so-called management gurus shaped the content of NPM and supported the reforms since they have different stakes in that (Pollitt, 1993: 8-10; 46, 47; 1996: 84; see also Hood, 1990a: 113; Rhodes, 1991: 548-550; Boston, 1991: 9; and Johnston and Callender, 1997: 53). Public administration scholars now suffer from what Bozeman calls "market fatigue" (1988: 672). They have tecome worried (Ventriss, 1989) and demoralised, perhaps because of the growing uncertainity about their professional future caused by the declining crebility of the field (Hughes,1994: 272; Holtham, 1992: 84). They are also in some danger of becoming irrelevant (Hughes, 1994: 272). Some of them are content with severly criticising NPM (see Keating, 1988; Pollitt, 1993; Elcock, 1991; Campbell, 1995), some others have reacted to NPM by reasserting that management function in the public domain is "unique" (Stewart and Ranson, 1988, and Ranson and Stewart, 1994) or by offering a radical approach to public administration (Dunleavy, 1982). Hood (1990a) described the predicament of the discipline of public administration well in his article named "Public Administration: Lost an Empire, Not Yet Found a Role?". As Jordon puts, the territory of public administration has been "balkanised" (quoted in Rhodes et al., 1995: 13). Business studies, economics and accountancy have occupied and colonised the field (Hopwood and Tomkins, 1984: 167; Power and Laughlin, 1992; Hood, 1995b: 170-172; Rhodes ct al., 1995: 13). Therefore, the future of public administration serms "bleak" (Rhodes et al., 1995: 14; Rhodes, 1996: 513). Although Dunleavy admits that public administration has had an appalling record of looking forward and correctly anticipating trends and future developments of central relevance to the subject, he believes that this anachronistic position is likely to recede a bit in' future as the current wave of reforms guided by NPM stabilizes and as many of its internal difficulties. He also argues that public administration as a discipline has now internalised many NPM ideas and is slowly rebuilding a management-oriented orthodoxy to replace its traditional approach (1994: 36-37; Dunleavy and Hood, 1994). However, in this situation, whether we can still call the discipline and its mainstream approach as "public administration" is a highly debatable point.

II. Changes in Perceptions and Priorities in the Public Sector: Economic and Political/Ideological Transformation Gave Rise to the New Public Management Approach

Administrative reform efforts before 1980s were undertaken as a technical activity to improve the administrative ability of government within the sphere of the traditional 
public administration understanding. However, governmental or administrative failure was considered as a political/ideological problem in addition to its technical (economic .and managerial) aspect in the 1980s. As we mentioned in the introduction section, the debate of the 1980s was about the "rolling back the frontiers of government" in the face of phenomenon of "big government". The focus was on "what" government organisations manage in the smaller, liberalised and commercialised government, with a more governance level (i.e. more external and economic) concern. In the 1990s, this noisy debate over government's role and size gave way to less ideological and more pragmatic one. The debate of the 1990s is, therefore, no longer the same though it is linked to the previous debate. The rolling back the frontiers of government policy has faced serious difficulties in carrying on some core public services. The driving force behind recent administrative reforms has clearly been, therefore, to provide at least the same level of public service with relatively fewer resources, given that most political regimes have not been willing or able to substantially cutback on public services themselves. Furthermore, even if the public sector is shrunk thanks to the privatisation of state owned enterprises, the problem of efficient use of resources in this smaller public sector has still been waiting to resolve especially for core public services financed through taxation. In other words, since there is a limit to achieve reduction in the relative share of the government in the economy, pressure to improve efficiency has increased. The focus has shifted to "how" government organisations are managed, with a more management level (i.e. internal and managerial) concern. It is realised that the efficient management of the public sector affects the private economy and national competitiveness and that improving management in the public sector is an integral part of the structural adjustments which are required for better economic performance in changing global environment since the public and private sectors are becoming more interdependent. This reality has forced the governments to search new system of ideas, structures, and practices which is appropriate to this relatively smaller public sector. Nevertheless, this new search in the public sector as the only viable political option has increased the dissonance between the government objectives and present administrative structures and processes. Therefore, a new task has emerged in order to have administrative structure and networks keep up with the economic and political/ideological transformation (see Muhammad, 1988; Prokopenko. 1989; Aucoin, 1991: 132-133; Keating, 1991: 235; Pollitt, 1993: 48; Hughes, 1994: 67-68; 256; see also OECDPUMA public management development surveys in the 1990s). The technical aspect of reform efforts has become dominant again to increase the efficiency and effectiveness of this limited government, but this time it has been treated within the sphere of NPM understanding (Hughes, 1994: 256).

\section{A. NPM as a Megatrend in the Public Sector}

As Christensen pointed out, the search for more efficient provision of public services has been expanded to a "general crusade" in order to reorganise the public sector by introducing new forms of management (1988: 55). In many OECD countries, national public sectors are radically transformed and restructured by introducing marketbased values (competition, innovation, value for money, customer responsiveness); competitive market conditions (competitive tendering, contracting-out, internal markets); decentralised structures and processes (decentralised, disintegrated, and deregulated civil service departments; devolved budgeting; ciecentralised and deregulated human resource management); and importing many other superior private sector management practices (new management information and performance measurement systems) (see Boston, 
1987, 1991, 1996; Aucoin, 1988, 1990; Shick, 1990; Caiden, 1991; Hoggett, 199.1; Hood, 1991; Stewart and Walsh, 1992; Isaac-Henry, Barnes and Painter, 1993; Mascarenhas, 1993; Ormond, 1993; Hughes, 1994; Peters and Savoie, 1994; Savoie, 1994; Holmes and Shand, 1995; Kouzmin, Dixon and Wilson, 1995; Foster and Plowden, 1996; Pollitt, 1996; Ingraham, 1997. Also see the OECD-PUMA public management developments surveys in 1990s. For recent developments in the Turkish public sector, see Ömürgönülşen, 1995; Tan, 1995; Ayman-Güler, 1996). In brief, this transformation has brought inportant changes in the relationships between market and govemment, govemment and bureaucracy, government and the citizenry, and bureaucracy and the citizenry. As a paradigmatic change, its effect on the study and practice of management of the public sector is also remarkable (see Hughes, 1994: 256; 278-279). The traditional public administration approach has almost been replaced by a new approach, NPM.

The rise of NPM over the last two decades is considered as one of the most striking "megatrends" in public administration (Hood,1989). Although the term NPM appears mainly in British administrative literature, it is not uniquely British devẹlopment. Hood (199()b, 1991: 3) has linked the rise of NPM with other major administrative megatrends since explanations for that development are not reduciable merely to the characteristics of a political leader or even to the accession to power of a political party. A complex set of short-run and long-run historical factors can join where explanations are sought (Willcocks and Harrow, 1992: xiii).

We can explain these political, economic and administrative trends briefly as follows (see Hood, 1989 and 1991; Wright, 1992: 35-36; Isaac-Henry, 1993; Mascarenhas, 1993: 320; Dunleavy, 1994; Farazmand, 1994; Hughes, 1994: 9-20):

(i) An intense "anti-governmental attack" on the size, role, values and practices of the government following a serious financial crisis. Since this ideological and political attack was extended to public opinion in the late 1970s and 1980s, public bureaucracy has become a useful scapigoat for financial difficulties, and then the "withdrawal of government" as an attempt to reverse government growth through cutbacks and privatisation and to redefine the role, values and practices of government through economic liberalisation and marketisation has become an official policy of many governments. This policy has also faced little effective opposition in the 1990 s since the political and economic environment has changed from centrally planned economy to market-based economy almost everywhere.

(ii) In the 1980s and 1990s economic theories (e.g. public choice, principal-agent, transaction-cost economics, and ownership rights) have provided theoretical backing for political and ideological attacking on the public sector. They have provided altematives, mainly market and commercial solutions, to the vague/fuzzy and bureaucratic notions of the traditional public service and then economic thinking has begun to replace the traditional understanding of public administration in the public sector.

(iii) A more "international agenda" has been developed for the study and practice of public administration. Public administration scholars and practitioners, now, live in what is much more of a "global village" conceptually. Since the public and private sectors are seen interdependent and the improving management in the public sector is considered an integral part of the structural adjustments need for better economic 
performance (i.e. higher national competitiveness) in a changing global environment, the structural and operational changes occured in the private sector in the post-Fordist era have also influenced the management function in the public sector. Leaner and flatter organisational structures and decentralised and flexible management style are prominent examples of this new era. The spread of ideas and the impact of "information technology" now occur so rapidly that national barriers are becoming increasingly artificial. A similar managerial reform agenda is now being implemented in many countries and the older tradition of individual country specialism in public administration is dying out by means of "globalisation". In other words, transnational pressures on nation states to standardise their policies will powerfully erode the existing single - country distinctiveness of public service markets. In brief, it can be said that globalisation, blurring the dichotomy between formally public and private spheres, rolling back the frontiers of the state, liberalisation and marketisation and structural (economic/administrative) adjustment reforms leading to "hollow state" are all interwoven processes.

These trends are not jointly exhaustive of developments in this field. They certainly overlap and are causally related. Thereforc, NPM is often interpreted as a consequence of a shift to "smaller government" and as a form of "inellectual privatisation" of the study of public administration (Hood, 1989: 350).

The emergence of NPM is not simply a matter of change in management style, but it is considered a "paradigm shift" to a new approach to the public sector. This new "paradigm" poses a direct challenge to the distinctive nature, culture, and fundamental principles of the traditional public administration. Supcriority of markets rather than hierarchical burcaucracy; responsiveness to consumers; a greater focus on results than processes, on initiative and responsibility rather than its evasion, and on management rather than administration, and a greater concern with value for money(economy, efficiency, and effectiveness) are becoming the new values of the public sector. The changes in approach and values in the public sector demand that public administrators should think, act and perform more like private sector managers who have greater concern with efficiency. As Jackson points out, nowadays NPM is considered as a means of improving public sector efficiency (1994: 121); and it is also generally accepted that market-type culture, structures, techniques, and managerial knowledge and skills are crucial for public sector efficiency (see Pollitt, 1993; Hoggett,1991; Hood, 1991; Stewart and Walsh, 1992).

Anglo-American countries (i.e. the U.S., the U.K., Australia, Canada, and New Zealand) have become pioneers in economic and administrative reform programmes. Many other developed Western countries have followed remarkably similar policies. Even Eastern European countries and many developing countries because of their economic and political dependencies on the Western world and their being under the influence of international financial institutions have in fact been launching similar policies. Not only conservative governments, but also social-democratic governments launched administrative reform programmes concerning decision-making, budgeting, decentralisation, human resource management, information technology, etc. in the 1980s and early 1990s (Muhammad, 1988; Caiden, 1991; Llewellyn and Potter, 1991; Wright, 1992; Butler, 1994; ILO, 1995; Mascarenhas, 1993; Massey, 1993; World Bank, 1994; and Haque, 1996b; Ingraham, 1997). 
Much of the existing literature on NPM comes from or is stimulated by the writings in Anglo-American world. However, there are some distinctive features among national reform programmes because the ideas have been put together with different aims and emphases and in different ways. Furthermore, the implementations have been achieved in different sequences and speed in those countries. Therefore, the transplantation of arguments and examples from the typical Anglo-American context to other contexts (e.g. continental European countries and especially developing countries) should be treated with caution. We need to be careful about over-generalisations on public sector reforins. For example, while in some countries the reforms may aim at reducing the role and size of the government (c.g. the U.K.), in others, they are perceived as defending and enhancing the government and then maintaining the legitimacy of the state (e.g. Australia, France and Scandinavian countries). The reforms in the U.S. are quite nonstrategic, at least until NPR of Gore (1993), and incremental. The experiences of the U.K. and Australia have proceeded in stages, but the U.K. has adopted a more ideological position in promoting private sector values and practices against those of public services while' Australia has tried to seck a general consensus on the reform by considering its constitutional difference. A more fresh and zealous start and comprehensive model influenced mainly by the new instutional economics has been adopted in New Zealand. Scandinavian countries have followed a more measured approach, while most continental European (administrative law) countries such as Italy, Spain and Austria have only achieved smaller changes. There are some countries where public sector reform is not major issue as yet - Germany and Japan. The role of politics and political leadership is also linked to the various models of reform. More comprehensive and strategic efforts require great initial political will and leadership but incremental efforts require more continuous political involvement. Therefore, a country's state tradition, system of government, its constitutional - legal system and legislative process, its political and administrative culture, the political leadership style in its politics; the existence and power of staff organisations, the stage of socio-economic development, and even its native language are country specific factors affecting the essence, direction and success of a reform programme (see Kooiman and Eliassen, 1987; Eliassen and Kooiman, 1993; Mascarenhas, 1993; Ridley, 1996; Harris, 1990; Holmes, 1992; Haque, 1996b; Pollitt, 1993: 193; OECD, 1993 and 1995; Stillman, 1997; Ingraham, 1997). Therefore, it is argued that managerialisation is much easier in Anglo-American countries because there is litile law involved, regulations are made and changed by the government, their administrative structure and tradition is more flexible than Napoleonic or Prussian types, there are large-scale and successful private sector examples in the economy, and mana'gerial literature is essentially developed in the English language (Ridlcy, 1996; see also Savoie, 1994). Despite these differences, the recent developments represent an obvious break with the bureaucratic traditions of many countries, in particular, of continental European countrics. As Holmes and Shand point out, the changes in the structure and management of national public sectors reffect greater convergence across the political spectrum. The convergence is apparent within the OECD countries, but it is also apparent in many developing countries, and in economies in transition (i.e the former centrally planned economies) since the basic principles of reform are relevant for every' country (1995: 554; 576-577).

\section{B. Political/ideological ties of NPM}

NPM is claimed to be a politically "neutral" approach within which many different values could be pursued effectively. Its proponents argue that different political 
priorities and circumstances could be accommodated by altering the "settings" of the management system, without the need to rewrite the basic programme of NPM. That framework is not, according to NPM's advocates, a machine exclusively tunable to respond to the demands of the New Right or to any one political party or programme (see for example, Scott, Bushnell and Sallee, 1990: 162; British Treasury and Civil Service Committee, 1990: ix, 22, 61). In this respect, Hood rightly argues that NPM followed the claims to "universality" of traditional public administration. It also purported to offer a neutral and all-purpose instrument for realizing whatever goals elected representatives might set (1991: 8; see Ostrom, 1974; and Hood, 1987) (12).

Every grand reform project represents a particular political/ideological vision (Gray and Jenkins, 1995). Therefore, the change from traditional public administration approach to NPM approach is, however, not innocuous and value-free as is often supposed (Jackson, 1994: 121). It could be argued that managerialisation in its broad sense is a deeper "ideological process" transforming relationships of power, culture, control and accountability (Clarke, Cochrane and McLaughlin, 1994a: 3). With some important exceptions, such as Pollitt (1993), Hoggett (1991), Hood (1991), TaylorGooby and Lawson (1993) and Clarke, Cochrane and McLaughlin (1994a, 1994b) this process has generally been presented as a transition from administrative rationality to an alternative (usually superior) form of technical rationality. Therefore, their emphasis is on "teaching" public managers how to change their practice (see, for example, Metcalfe and Richards, 1990; Willcocks and Harrow, 1992). The main critical view of NPM, on the other hand, has dismissed it as little more than a "fad" or an "ideological smokescreen" behind which disinvestment, privatisation and increased exploitation of labour are hidden (see, for example, Johnson, 1990). In contrast, the process of managerialisation is neither merely a politically neutral and rational informationprocessing/decision-making black box nor a smokescreen which conceals more significant events. Instead, it could be argued that managerialisation constitutes the means through which the structure and culture of public services are being recast. In doing so, it seeks to dismantlc the "old" consensus and then introduces new orientations and remodels existing power relations (bureau-professionalism) within and around the welfare state and affects how and where public policy choices are made. Within this context, NPM has strengthened the political project of restructuring the state by providing relatively new systems of authority, control and motivation to unlock the bastions of the traditional (burcaucratic and professional) model of public administration. Thus, NPM has been forged out of a complex articulation between changes in the realms of both politics and management. It has, in ccrtain instances, politicised rather than depoliticised public service issues. This is why NPM matters (Clarke, Cochrane, McLaughlin, 1994a: 4; 1994b: 227, 231, 232; and Newman and Clarke, 1994).

It seems that there is a "casual" relationship between "New Right" policies, formulated as an "alternative" to the ongoing "crisis" which has emerged as a result of Keynesian economics and the welfare state, and the "public management" thesis (see Üstüner, 1992: 99-101; 1995; also see Aksoy, 1995; Ozen, 1995). The origins of public management (especially NPM) have been attributet to New Right ideology though its roots lie further back in Scientific Management theory and some official reform reports such as the Fulton Report (1968) for the British Civil Service. NPM and recent public sector reforms guided by NPM emerged out of the coincidence of particular circumstances, both economic (decline in profit rates and increase in world-wide competition coming mainly from Far Eastern countries; petrol shocks; relatively slow 
rate of growth due to mainly crowded-out public sector), social (rising expectations about public services and change in demographic structure) and political (general public disenchantment with government and, in particular, with the quality of public services; and then a shift in political ideas about the role of government) present - albeit to varying degrees - in the Western World which characterised the last quarter of the twentieth century (sec Hond, 1991; Mascarenhas, 1993; Pollitt, 1993; Zifcak, 1994). Although there is some truth in the view that the rise of NPM is a prime result of the economic/financial crisis - recession combined with increased international competition (see Schwartz, 1994; and, Thompson, 1997), such economic and financial pressures do not solely explain the content of public sector reforms. In the second half of the nineteenth and the first half of the twentieth centuries, increased international competitiveness and depression seem to have inevitably led to more government, more bureaucracy and greater reliance on hierarchical and centralised solutions (Thompson, 1997). On the other hand, in the 1980s and 1990s, economic theories (e.g. public choice, principal-agent, transactior - -cost economics, and ownership rights) provided theoretical backing for political and ideological attacks on the public sector; and the structural and operational changes in the private sector have influenced management in the public sector by means of the trend to globalisation (Hughes, 1994: 9-20). In other words, capitalism saved itself by creating gerieral consensus on Keyncsian economic management and the welfare state. However, this policy could not save the capitalist system from crisis this time, and furthermore, it has been seen as the main reason for the crisis (Şaylan, 1994, 1995). The international economic crisis, it was considered, could be solved by more market-oriented policies and economic liberalisation, but globalisation of national economies seemed inconsistent with prevailing government polices, largely confined to national boundaries. Governments and the public had to be convinced of the necessity and benéfits of economic liberalisation and marketisation, followed by the reform of the public sector (Mascarenhas, 1993: 320). New Rightist ideologues and conservative politicians had plentiful ammunition with which to bombard their opponents with the glaring government failure and discomforts of the 1970s and with the help of right-wing think tanks and international financial organisations (Economist, May 6,1989: 62-64; Pollitt, 1996: 84). They captured and exploited citizen dissatisfaction and then translated it into demands for smaller, icaner and more responsive government(Ingraham, 1997: 326). As a matter of fact, nowadays, government intervention is no longer seen as desirable; the private sector is held up as a model of economic efficiency in contrast to the monopoly ridden public sector (Minford, 1984). Instead of traditional administrative means, some kinds of privatisation and the introduction of private management practices are remedies offered by the circles of the New Right to enhance the competence of government in order to resolve the "crisis". Farnham and Horton argue, therefore, that it is not too much to claim that NPM is, to some large degree, a by-product of the ascendancy of New Right ideas. Without the shift in emphasis from politics to markets, from welfare to enterprise and from state monopolies to the "new model" cnabling state, the managerialist ideas and practices based on private-sector orthodoxy, would not have taken root as they have dorie(1996a: 23).

In the U.K., Mr. Heseltine (1980), as a former Secretary of State for the Environment, said: « Efficient management is a key to the [national] revival ... And the management ethos must run right through our national life - private or public .... ». In the private sector, NPM has been essentially "market-driven". The changes in private business have sometimes been enforced upon a frightened and reluctant workforce by "macho" style of management. In addition to the common view about the technical 
superiority of private sector management techniques and practices over traditional public administration ones, NPM has been "politically-driven" in the public sector. As Pollitt writes, for the New Right, better management provides a label under which private sector disciplines can be introduced to the public services, political control can be strengthened, budgets trimmed, professional autonomy reduced, public service unions weakened and a quasi-competitive framework erected to flush out the natural "inefficiencies" of bureaucracy (1993: 49).

Thus it can be seen that there is a highly developed political agenda underpinning NPM in the public sector. NPM and current public sector reform programmes, in brief, are a distinctive element of New Rightist policies towards the public sector (Pollitu, 1993 and 1996; Mascarenhas, 1993; Gray and Jenkins, 1995; Rhodes et al., 1995; Farnham and Horton, 1996b: 42). The different strands of New Right ideology (i.e. economic liberalism, political conservatism) have formed a philosophical base and atmosphere for NPM and public choice theory has provided its institutional and operational framework. New Rightist political parties and leaders who were quite hostile to govemment bureaucracy in the Anglo-American world (especially in the.U.S., the U.K., and Canada) have put anti-governmental policies into practice. They have sought to perform radical surgery on the bureaucracy. "Bureaucrat bashing" became a popular sport among conservative politicians (Campbell and Peters, 1988; Peters, 1989 and 1991; Gormley, 1989; Peters and Savoie, 1994; Savoie, 1994). These politicians saw the opportunity of linking anti-government feeling in public opinion (13) with New Rightist solutions developed by academics (Pollitt, 1993: 45). Public support for the Reagan and Thatcher administrations could be explained by a public reaction to "bureaucratic paternalism" (Hoggett and Hombleton, 1987) or, in other words, to professional-dominated and customer-insensitive service provision (see Stewart, 1983). This was highly succesfully exploitated by both the New Rightist politicians and academics.

Pollitt argues that managerialism, in particular, is the "acceptable face" of Ncw Right thinking concerning the state and that idcological considerations may be part of the argument for reducing government (1993: 49). Some other authors regard NPM as a simple vehicle to make national economies more open and integrated to the world economy; and they see causal relationships between New Right ideology, globalisation and economic/administrative restructuring (structural adjustment) initiatives, recolonisation effforts and NPM and governance theses (for example, sec Ayman-Güler, 1994, 1996 and 1997; Saylan, 1994 and 1995). They also argue that many scholars use the NPM framework without questioning its idcological or methodological implications. According to them, the most dangerous aspect of the shift to NPM without considering publicness dimension is the power of NPM in creating a de facto situation supporting the privatisation or marketisation of public services without allowing enough debate (sce Ayman-Güler, 1994: 7, 18). Within this context it is not surprising to sce the links both between New Right policies and the current status of the discipline of public administration (see, Kingdom, 1990; Chandler, 1991: 39-40) and between New Right policies and the repudiation of the traditional public administration approach.

One significant point should be clarifed in terms of the links mentioned above. It would be too much to suggest that conservative governments in the Western world since the late 1970s have simply been vehicles for the New Right. What is clear is that New Right ideas have had a great influence on politicians and governmental policies. But, 
some conservative governments (c.g. the Reagan, Thatcher and Mulroney governments) were much more committed to the reforms than other conservative governments in the Westem world (e.g. Kohl and Chirac governments) (Savoie, 1994). It should also be kept in mind that proponents of Neo-Marxism and new social movements such as feminism, anti-racist and green ideologies, and the idea of civil society indirectly helped New Rightist theorists and politicians to break down the post-war consensus by severely criticising the bureaucratic and oppressive nature of the welfare state (14). In addition, left-óf-center governments (i.e. Labour governments in Australia and New Zealand; leftist governments in Denmark and Sweden; and probably the new Labour government in the U.K.) have also undertaken similar reform programmes though they are not as ideologically-oriented or enthusiastic about these reforms as conservative governments (see Mascarenhas, 1993; also Johnson, 1993; Farnham and Horton, 1996a and 1996c; Schwartz, 1994; Kirkpatrick and Martinez Lucio, 1996; Ingraham, 1997). Furthermore, in thẹ U.K. for instance, from Fabianism through to "new urban left" or "municipal left" thinking on urban governance made some managerial ideas more politically acceptable in Labour-controlled British local governments in the 1980s (see Gyford, 1985; Blunkett and Jackson, 1987; Hogget, 1991: 248).

Although NPM is closely related to New Right ideology and to all these megatrends toward a "smaller-limited but strong state", it is more than a simple administrative vehicle of it. It would be too simplistic to place NPM solely in relation to New Right ideology and political project. Such a conclusion represents a partial and incomplete reading of the changes that have occured in the 1980s and 1990s. It could also leave the critics of NPM with nothing more than a politics of nostalgia for the "old" arrangements as the only way of coordinating the provision of public services of which, in the past, they themselves have frequently been the harshest critics (Clarke, Cochrane and McLaughlin, 1994b: 2\%7). As Hughes aptly points out, to regard NPM as only an ideological occurance ignores the general argument which stems from different ideological standpoints against bureaucracy as an organising principle and burcaucratic form, of decision-making and service provision. Bureaucracy as an organising principle has clearly lost ground in the private sector, so the extension of this to the public sector may be less a matter of ideology and more a response to its theoretical failures. Privatisation leads to a shrinking of government, but what remained of government could still function in a traditional bureaucratic way since improving efficiency has a logic of its own. The movement against bureaucracy could occur regardless of size or in addition to the size problem and may prove to be more fundamental and more sweeping than a reduction in the size and role of the public sector (1994: 20-21).

It should also be kept in mind that one does not have to be a right winger to believe that traditionally government performance is low and needs to be improved. The consensus on the need for change in the management of public services have bridged party' divisions. This is the case for Democrat Clinton administration which launched National Performance Revicw (Gore, 1993). The new Labour government's position in the U.K. is another strong indicator of this reality. Thus, broad political support for reform programmes guided by NPM makes it difficult to read it politically not just becaúse it represents itself as being "apolitical", "value-free" and "technical". Consequently, because of its apparent capacity to be rearticulated within various political positions, NPM is likely to outlive New Rightist administration (see Clarke, Cochrane and McLaughlin, 1994a: 5). However, as Kirkpatrick and Martinez Lucio have emphasised, this is not to suggest that a social democratic variant will be the same one. 
More attention could be paid to the roles of various political actors (i.e. interest groups, consumer bodies, local authorities, and alternative political networks) (1996: 7). In some countries such as Australia, left of center politicians have launched similar reform programmes but have not given so much credit to bureaucrat bashing (see Ingraham, 1997: 327) as a starting point or justification of changes; in contrast, they have sought the cooperation of public servants and their unions (see Mascarenhas, 1993).

In brief, it can be said that the transformation in the economic and political/ideological environment of the public sector is not only a rhetorical debate or a cosmetic change; and that, in addition to some exploitation and manipulation of New Right ideology, it is a natural consequence of serious uneasiness stemming from the structure and functioning of the traditional public sector.

\section{Conclusion: Irreversibility of NPM?}

The debate about "resurrection/revolution" of administrative reforms comes into agenda from time to time. Many of today's reforms in the public sector are actually embedded in those of yesterday, from Fulton to Rayner in particular in the case of the U.K.. So we may observe "continuity" in the reform commitment and in some NPM prescriptions (Wright, 1992: 33) but the application of those by committed governments in a rather different political and economic consensus can be considered as a "revolution" or a "new" paradigm.

The significance of current public sector reforms guided by NPM compared with past efforts is that they are more rapid, strategic and comprehensive and aimed not atmaking minor changes but at altering the relationship between the public and private sectors of the economy by essentially re examining the role of government in social and economic life and promoting fundamental values such as freedom of the individual, customer choice and greater initiative for the private sector in cconomic development. They are closely linked to New Right idcology and in many cases they are supported wholeheartedly and strategically by conservative political leadership (see Campbell, 1995: 488; and Mascarenhas, 1993: 319; Holmes and Shand, 1995: 522).

There is also a serious question about NPM linked closely to the debate mentioned above: whether it is a lasting change in ideas with substance, or merely a fashion or fad that is simply a hype of old ideas in a new package which is bound to fail (see Hood, 1991; Wright, 1992). Following the failure of many administrative experiments, the feeling about NPM is quite understandable. However, there is some basis for believing that NPM will be a longer lasting set of prescriptions or programme than earlier reforms. Unlike the previous internal management reforms within a bureaucratic framework, this programme has received strong support from politicians, managers, some professions, and the public since they have different stakes in NPM and they are all very critical about the bureaucratic administration model (Hughes, 1994: 263264).

In the beginning of the 1990s, one of the leading scholars in this field, Hood argued that the managerial approach has no intellectual superiority over the old orthodoxy in public administration in terms of principles for organising public services (1990a: 113-1 14). However, in the middle of the 1990s, Hood admitted that NPM seemed successful, in particular, in terms of the durability and continuous development of 
organising principles (see Dunleavy and Hood, 1994). But it does not mean that Hood wholeheartedly accepts NPM as a "single" and "global" paradigm which is a very popular claim made explicitly by Osborne and Gaebler (1992). Aucoin (1990: 134) and Barzelay with Armanjani (1992) alsc mention this new international paradigm. Hood (with Dunledvy) is sceptical about the argument of new global paradigm. He accepts that there has been a trend away from traditional ("progressive" in his own terms) public administration in many developed countries but this partial retreat does not necessarily demonstrate that any single and universal paradigm will inevitably replace the traditional one. The "globality", "uniformity", "coherence" and "monoparadigmatic" character of contemporary public management change seems to be exaggerated. Hood argues that the future of public management may be more "plural" and "contradictory" than the sweeping prognastications of Osborne and Gaebler might lead us to think. Therefore, we need to know/more about the "different agendas" that may underly the same slogans (see Dunleavy and Hood, 1994: 13; Hood, 1995a, 1995b: 168-170, 1996).

However, it should be noted that although each country has put emphasis on different themes and strategies of NPM at different times, each has adopted the main philospohy of NPM and has tried to achieve these reforms within the general NPM framework. This makes NPM the strongest paradigm of today and, possibly, of the near future. It is feasible for NPM to continue or intensify for many years before triggering a fundamental reconsideration or a serious public opinion backlash.

Therefore, it can be argued that there appears to be a "new political consensus" emerging, in place of the post-war settlement, which is rooted in the acceptance of the mixed economy of welfare and NPM (Horton, 1996: 176)(15). Even the British Labour Party', in the process of reform in the 1990s, has become more attached to the vision of an enabling state, endorsing citizens' rights and quality of service provision and managerialist practices by discarding its out of fashion ideological baggage which was closely related to the post-war consensus. With the election of Mr. Blair to the leadership of the "New" Labour Party in 1994 and the Party's distinctive shift from centre-left to the centre of British politics, the free market and enabling state model seem unlikely to be challenged by leading British politicians in the foreseeable future (see Johnson, 1993; and Farnham and Horton, 1996a). As a matter of fact, the New Labour Party won the April 1997 elections with this pragmatic programme. This programme has influenced not only the British left, but many other social democrat'socialist parties and governments of both developed Westem countries and some developing countries.

The "culture" of the public has been changing too. People are demanding not only more services but also cheaper and better quality provisions. At the same time people and interest groups are questioning the values, motives and competence of bureaucrats and professionals. They are beginning to act more like "customers" than "clients" (IsaacHen'ry, 1993: 4).

As Jack Welch, Chairman of General Electric recently explained, the centralised and bureaucratic procedures were « right for the 1970s, a growing handicap in the 1980s, and would have been a ticket to the bone yard in the 1990s» (quoted in Thompson, 1997: .175). This is also true, to a great extent, for the public sector.

NPM seems to be a worldwide phenomenon because it is a manifestation of a fundamental transformation affecting nearly every corner of the globe. Similar practices 
have simultaneously become current in many different countries and under political regimes of different persuasions. A new model of public management has almost supplanted the traditional model of public administration. The fundamental logic of this new model (i.e value for money) is now widely acepted, providing the frame of reference within which decisions must be justified. Alternative forms of legitimation and justification associated with equity have been marginalised. While most public activities are becoming "managerialised" so 100 almost everybody in the public sector have had to re-image themselves and redefine his role within the framework of NPM. Therefore, there has been an increasing degree of "consensus" on NPM though it may be varied in different contexts. Some of the absurdities of "managerially correct" language and practice will have abated, but there is "no possibility of going back" to traditional public administration. The public sector in the future will inevitably be more managerial in both theory and practice (Hughes, 1994; see also Dunsire, 1995). Therefore, NPM or in other words managerial revolution, seems "irrevcrsible" (see Metcalfe, 1993: 351, 352, 369; Hughes, 1994: 22, 260, 278; Clarke, Cochrane and McLaughlin, 1994a: 5, 1994b: 227,229 ).

Some will be pleased by this conclusion (e.g. Peat Marwick, 1986; OECD, 1995; World Bank, 1995) since they do not see any other "real" alternative, others perhaps less so (e.g. Elcock, 1991, 1995; Pollitt, 1993). However, it should be emphasised that NPM's effects on the public sector are not always positive, in contrast to the claims. In addition to many beneficial results in terms of government performance, it has some potential problems and dangers. Furthermore some negative effects have already appeared as is claimed by critics such as Pollitt. Unclear specification of NPM (all rhetoric no substance argument), its political/ideological neutrality and universality claims, the role of NPM in interest relationships in society, its effect on the politicisation of administrative system, its nco-Taylorian and cconomistic character, contradictions between market culture and values and the traditional public service culture and values, internal contradictions between its theoretical bases, the possibility of portability of private sector management techniques and practices into the public sector, the erosion in the public accountability, and the deterioration in the morale of public servants are the main criticisms directed to NPM. It is also argued that the cultural change guided by market-based and managerial values will eventually undermine the values of the public domain (c.g. equity, justice, impartiality, citizenship rights, public interest and public ethic, and public accountability). The remodelling of the public sector, therefore, remains "business unfinished" rather than "mission accomplished". Destabilisation which has been created by NPM has provided new possibilities for radical changes in favour of both managers, employees and service users, but many scholars are still sceptical about whether the conditions underlying these changes can, in fact, deliver on these multiple promises. In other words, the possibility of positive-sum game is questionable (see Clarke, Cochrane and McLaughlin, 1994b: 230, 239-240). Therefore, it seems there is a long way to go in restructuring the public sector. Neither traditional values and mechanisms of public administartion such as the vague notion of public interest and the politics/administration dichotomy, nor managerial and commercial values and mechanisms, such as efficiency, are enough to explain and solve the complex problems of the public sector on their own.

Anti-government doctrines that reached their apogee at the end of the 1980s, have begun to wain to some extent. Although the limitations of NPM are being increasingly acknowledged both in the political and academic worlds, no single and strong alternative 
has yet emerged or managed the kind of dominance which NPM has achieved. "Public service orientation" (Clarke and Stewart, 1986), "management for the public domain" (Stewart and Ranson, 1988; Ranson and Stewart, 1994) or "public management as an integrative approach" (Perry and Kraemer, 1983) has yet to be - and may never be popularised and taken up by major political parties or the academic world (see Pollitt, 1993: 148; and 1996: 86). As a matter of fact, some scholars have already switched their attention to search for a new approach to or vision for the management of the public sector. The new but complementary approach called "governance" (see Kooiman, 1993; Dunsire, 1995), and even "postmodern" public administration theory (see Hussard and Peker, 1993; Fox and Miller, 1995) are given as examples, despite the current dominance of NPM in both study and practice in the public sector. In our opinion a distinctive approach to public management has to be developed. If it is developed, Perry and Kraemer's integrative "public management" could be a useful starting point. This effort must take account of the distinctiveness of the public sector, while still recognising the need that the managerial work must be done with an acceptable level of performance.

Improving the performance of the public sector is the crucial point of the recent reform efforts. The very nature of the purpose of improving efficency in the public sector makes « the adoption of a managerial approach necessary, but the kind of management must be specific to the conditions of the public sector» (OECD, 1991: 10). Managing the public sector well will require an understanding of the "distinctive nature" of management in this sector, and in the public service in particular. Any initiative must show an understanding of the particular legal and socio-political environment within which the public sector operates in addition to economic and financial constraints. Therefore, the public sector must develop its own management ethos and style, based around the concept of public service which has always been its guiding principle (Boyle, 1992: 245-246). In fact, as Hughes aptly points out: « what we are witnessing may be a new theory of management, but, thus far, it is a theory of public management and not a generic management» (1994: 86). Public management will not be derived merely by transferring private management techniques to the public sector, but rather by consideration of what the general management function entails, what the peculiar features of management in the public sector are and the derivation of a new system of management which suits that sector (Hughes, 1994: 86).

Public management is neither a function of mere application of public law and administrative procedures nor a function focusing only on achieving objectives by using some economic criteria and managerial techniques without considering any social and political criteria. On the one hand, the denial of the importance of cost-consciousness and sticking to the bureaucralic rules are among the main causes of bureaucratic inertia. Therefore, there is no doubt that economics and management are necessary pillars of public management. Significant improvements in the performance of public organisations can be expected from improved approaches to management. On the other hand, economics and management cannot solely form an adequate foundation for public management. An exclusive focus on value for money and management may never be entirely appropriate in the public sector. The denial of the different demands on management in government and therefore the application of generic management principles is a dangerous fallacy. Public management does not exist apart from sociopolitical issues (c.g. equity, participation) and public law (i.c. the constitutional order). The study and practice of public management without legal and socio-political contents should be seen as pointless: and artificial (see Chandler, 1991). An opposite understanding 
will facilitate the identification of public management with generic or private management. Eventually, public management will die out in the field of generic management. Departing from this point, public management should be reconsidered as an approach beyond the narrow concept of the technology of public administration; and not only its instrumental aspect but also its normative aspect should be enriched (see Butler, 1994). The problem, which we are now facing is that of how the best of both approaches can be synthesised. Unfortunately, both the advocates of traditional public administration and NPM have showed relatively little concern in this crucial matter (see Wilson, 1996). In our opinion, public management should be a coherent combination of applications of legal, economic and managerial rules in order to provide public services expediently, efficiently and effectively. In the long-run more efficient and effective public management based on a greater concern for economically rational results may be vital to sustaining support for government policies to improve social aims (see also Keating, 1991: 238, 262-263). A new approach to public management, therefore, should be developed with an integrative understanding of the contribution of politics, public law, economics and management (For a similar argument, sec Ranson and Stewart, 1994: 3031; Johnston and Callender, 1997: 54; Şaylan, 1995: 118-119). We hope that an enriched public management approach will provide a broader perspective from which to analyse the phenomenon of limited but efficient government. We are aware of the difficulties and contradictions of this task, but we believe that in the late 1990s enough knowledge and experience has accumulated to permit such an approach to be developed.

The last decade was devoted to legitimising public management with considerable success. As Perry argues, we are now entering a more serious stage, in which valued knowledge must be developed (1993: 16). We have still little knowledge about public management, especially as compared to generic or business management. We need both researchers and practitioners to devote sustained and serious attention to developing our knowledge for public management (see Rainey, 1991: 7, 11). However, the value of public management will be limited unless we establish a conceptual bridge between political rationality and economic rationality( see Levine, 1979: 471, 484, 485) and between managerial rationality and the rationality of public law (sce OECD, 1991: 13; and also Peters, 1989: 296). This sort of synthesis may be an idealistic view since the management of public affairs is not an easy task, but it should be done (see Hughes, 1994: 257-258). Thus, the key substantive issue, which is still how the inherent conflict between the private management model with its criteria of economic efficiency and the public administration model with its criteria of public interest, could be resolved. The public management approach has raied this issue correctly, but a long and painstaking road is waiting for it to resolve the issue meaningfully. Furthermore, public management should not be considered as a certain remedy for all public illness (see Kooiman and Eliassen, 1987: 15-16). Indeed, public management is only a promising direction rather than a full panacea. It does not represent some miraculous elixir for all problems of the public sector (see Rainey, 1990: 172, 173). Therefore, public sector is not likely to be the comfortable place for both academics and practitioners as it was before the 1980s.

\section{Notes:}


(1) For the difference between "administration" and "management" functions, in particular in the public sector context, and the phenomenon of transition from administration to management, sec Hughes (1994: Chp. 1).

(2) For wide variations in approach, see Rainey (1990). For a stronger argument, see Bozeman (1993: 361-36i2).

(3) Due to short of space we cannot elaborate this point. For detailed information, see Aucoin (1988, 1990); Hoggetu (1991, 1996); Holmes and Shand (1995).

(4) For the U.K., see Jones (1989); Pollitt (1993); Metcalfe (1993); Painter (1993); Overman and Boyd (1994); Horton (1996). Also see Major (1989); Butler (1992) as public figures. For Commonwealth countries, see Borins (1994). For the U.S. and Canada, see Aucoin (1990); Barzelay with Armanjani (1992); Lan and Rosenbloom (1992); Osborne and Gaebler (1992); Gore (1993); Kernaghan (1993). For the debate on paradigm shift and paradigmatic crisis in the Turkish public administration literature, see Üstüner (1986, 1992, 1995); Uysal-Sezer (1992); Ayman-Güler (1994, 1997); Aksoy (1995); Ergun (1995); Şaylan (1996).

(5) For a contrary view, see Toulmin (1970;) Bay (1972); Golembiewski (1974:174). For a general cvaluation, see Lovrich (1985).

(6) NPM's position in terms of this dichotomy is quite different. Kingdom argues that it is a considerable irony that NPM as a new movement is premised upon such an outmoded axiom (1986b: 17). However, the dichotomy is supported by NPM with the understanding that managerial practices can be used in both the private and public sectors since political influence, which is the distinctive characteristic of the public sector, is averted by this dichotomy. Political process is viewed, in general, as an impediment to efficiency (sce Pollitt, 1993: 189). Thus, political neutrality at middle and lower levels of the public bureaucracy can be maintained, and the transplantation of managerial practices into the public sector can be achieved by leaving out political influences on public organisations and agyents. The arca of influence of carcer bureaucrats is confincd to policy implementation and management by making them managers of their units through decentralisation, delegation and devolution (i.e. policy-making/management dichotomy). They are asked to implement government policies in a most efficient and effective way. On the other hand, NPM ignores the dichotomy where the higher level of the public bureaucracy is concerned. But it does not mean that senior burcaucrats are allowed to shape policies as in the case of the traditional public administration model. It means an intensified politicisation of the highest echelon in the pursuit of the political goals of its political masters. The erosion in the career notion in the public sector through the rejection of security of tenure and the introduction of contractual relationships has increased the level of politicisation at the highest echelon of bureaucracy in the Anglo-American world (see Long, 1981; Newland, 1983; Pfiffner, 1987; Volcker Commission, 1990; Maranto and Schultz, 1991; Mascarenhas, 1993). In addition to politicisation, for example, Mrs. Thatcher had personalised the selection of senior bureaucrats in Whitehall (Campbell, 1995: 488). She did not want policy advice from senior bureaucrats and this has weakened the policy advice capacity of those bureaucrats (Savoie, 1994). In brief, while political and technical rationalities are effectively blended by increased politicisation at the governance level (with the effect of public choice arguments on tight control of bureaucrats due to vested interets at higher- 
level), policy-making/management dichotomy is strictly pursued at management level (with the effect of managerial arguments on loose control-devolution and autonomy-on managers at middle and lower-levels). For a contrary view, see Yeatman (1993). However, even the depoliticisation at management (operational) level is being driven by the most politicised restructuring the public sector has ever seen. Within the boundaries of predetermined strategic framework, line managers act with relatively higher autonomy on the basis of technical rationality. This sort of interpretation of the dichotomy seems more realistic than traditional dichotomy interpretation. It also facilitates the application of NPM principles to the public sector.

(7) The politics/administration dichotomy is usually associated with Wilson and Weber. Although writing for different reasons and from distinct intellectual traditions, both writers developed the idea to separate the policy-making from the policy implementation. There was greater anxiety about the usurpation of administrative powers and functions by politicians than there was about ensuring the powers of those politicians (Campbell and Peters, 1988). A good part of the justification for the separation of politics and administration in Wilson's writing (1887) was to give greater latitude to the administrative officials to exercise their own independent powers and discretion (Doig, 1983). Wilson wanted government to be managed very much like a business, and to reach that dream required the removal of political meddling. Also, rather than being a defender of politicians, Weber can be seen as attempting to protect the state from the excess of politicians (Campbell and Peters, 1988). Despite their original intentions, the writings of Wilson and Weber have been largely interpreted as an attempt to restrict administrative involvement in policy-making. This is certainly the manner of those who were representatives of "scientific administration" era (see Goodnow, 1900; Gulick and Urwick, 1937), and those who declared that dichotomy dead (see Friedrich, 1940. Appleby, 1949; Aberbach, Putnam and Rockman, 1981). In the contemporary politics and public administration, either this dichotomy is used as a mean of preserving and justifying the powers of the political executive or it is completely denied since there is no clearcut division between political and administrative functions. However, the dichotomy is revived in the 1980s and 1990s (see Waldo, 1990; see also footnote 6). It can be asked that why has this dichotomy had such durability? According to Campbell and Peters (1988), it has survived as a convenient fiction rather than a description of any reality since many groups (c.g. politicians, senior bureaucrats, street-level bureaucrats) have diferent stakes in its preservation.

(8) This tendency can be clearly seen in many recent publications in this field. For example, see Kooiman and Eliassen (1987); Jackson (1988, 1990 and 1994); Taylor and Popham (1989); Flynn (1993-first edition in 1990); Metcalfe and Richards (1990first edition in 1987), Lawton and Rose (1994-first edition in 1991); Famham and Horton (1996d-first edition in 1992); Willcocks and Harrow (1992); Bozeman (1993); Eliassen and Kooiman (1993); Isaac-Henry, Painter and Barnes (1993); Hughes (1994); McKewitt and Lawton (1994); Lynn (1996).

(9) For the concept of "identity crisis", see Waldo (1968: 5). Waldo argues that identity crisis emerges when both the nature and boundaries of the subject matter and the methods of studying and teaching this subject matter become problematical. Due to the interdisciplinary nature of public administration and continuous borrowing knowledge from other disciplines (McCurdy, 1986: 11-16), it is argued that the discipline of public administration could not develop around an integrated centre (Waldo, 1975) and, thus, it 
faces an identity crisis (Houston, 1993). Some authors, by taking a step further, claim that public administration is: no more than a bulk of knowledge borrowed form other disciplines and it is not even an independent field of study (McCurdy, 1986: 15). Actually, although it has a century-long history, it is argued that defining public administration still as an "iriterdisciplinary discipline" or taking a "middle-of-the road" position by emphasising its close ties with political science or management is the same thing as denying its existence and necessity as an independent discipline (see AymanGüler, 1995: 4). This, of course, reinforces the identity crisis of the discipline.

For the concept of "intellectual crisis", see Ostrom (1974). He describes intellectual crisis in a situation in which the agreed-on bases of theory fail to reflect or respond to the nceds of actois in the field - theorists, practitioners, and citizens.

Recent expressions of these recurrent concerns include Hood (1990a, 1990b); Kass and Catron (1990); Lynn and Wildavsky (1990); Rhodes (1991); and Stillman (1991); Haque (1996a, 1996b). For a postmodernist view of the identity crisis in public administration, see McSwite (1997). For the identity problem of the study of public administration in historical perspective, see Rutgers (1997). Haque claims that the nature, intensity, and severity of intellectual crisis have changed today due to the worldwide movement tow:ards privatisation (1996a). The privatisation movement has challenged the legitimacy of public service (i.e. decline in public confidence in government and public service), public service ethics (i.e the replacement of traditional values and norms of public service by pro-market ones), and public service motivation (i.e. decline in moral and motivation of public servants) (Haque, 1996b). These challenges in practical spheres of the public sector have directly affected the study of public administration. According to Haque, the current crisis in public administration takes three main forms by affecting the credibility, norms and confidence negatively in academic and professional public administration. There are also causal relationships between the three modes of intellectual crisis in that they reinforce cach other (1996a).

Managerial reforms in the public sector are likely to bring some bencfits at operational level, but they shake the normative and constitutional bases of public administration and give rise to loss of the soul of public administration (sec Hart and Wasden, 1990; Green, Keller and Wamsley, 1993). However, some authors are more optimistic, arguing that the current reform efforts in the public sector do not signal an intellectual crisis in the field; rather, they mark opportunities for change in both the practitioning and research communities (see Kingsley, 1997). For a general evaluation on this point, see Lovrich (1985).

(10) Public administration as a field of study has been in turbulence recently. The question of whether public administration is a scientific discipline or not is still a troubling matter commented on by many scholars. Sce Waldo $(1968,1972)$; Golembiewski (1977); Dinhhardt (1982); Bozeman and Straussman (1984); Kingdom (1986a and 1986b); McCurdy (1986); Hood (1987, 1990a); Ventriss (1987); Chandler (1988, 1991); Henry (1939); Rosenbloom (1989); Bhattacharya (1990); Frederickson (1990); Midwinter (1990); Lynn and Wildavsky (1990); Rhodes (1991); White and Adams (1994); Rhodes et al. (1995); Haque (1996a); Merino (1996); Rhodes (1996).

(11) Instead of NPM, it is argued by some authors that only a proper understanding of the concepts of "public" and "publicness" and a comprehensive "public 
perspective" provide a sound intellectual foundation to alleviate the field's current crisis (see Ventriss, 1987, 1989, 1991; Coursey and Bozeman, 1990; Frederickson, 1991; Ranson and Stewart, 1994; and Haque, 1996a). Dunleavy's (1982) "radical approach" (in neo-Marxist or Marxist-structuralist discourse) and "Blacksburg Manifesto" proclaimed by some scholars from Virginia Polytechnic (see Wamsley and Bacher, 1990) can also be mentioned as critical approaches to the identity crisis of public administration (sce Üstiuner, 1995). There is growing unease among orthodox/radical public administration scholars in Turkey about the recent ideological and methodological developments in this field. For example, it is often argued that the phenomenon of public administration is being sterilised by the tendency to managerialism with the reassertion of the traditional politics/administration dichotomy. Thus, the phenomenon of public administration is exposed as only a technical and neutral activity and its social and political dimensions are neglected and even concealed. Managerialisation shifts the focus of the discipline of public administration from discussions on the substance to instrumental rationality (see Ayman-Güler, 1994; Aksoy, 1995; Üstüner, 1995). Üstüner (1992, 1995) also argues that suggestions made to overcome the identity crisis in this field are, unfortunately, mainly at "cpistemological" level (technical and practical questions about administrative reforms) and ignore "ontological" questions, and therefore they block the way-out, create a vicious circle, and then prolong the crisis. The "technology of public administration" must be left to practitioners, and scholars must concentrate on the "academic activities of public administration" (i.c. ontological concepts and questions) such as the state and its organisation, public interest, democratic administration, hierarchies, and the privileges of the rulers. He argues that if it is not supponcd by the reality that public administration is a significant part of the state and the socio-political dynamics of society, this will be a very narrow perspective that will facilitate the identification of public administration with private management and eventually results in the diminuation and dying out of public administration in the field of management. He claims that the so-called "identity crisis" of the discipline of public administration cannot be overcome by limited solutions (i.e. the technology of public administration) carried out by the practitioners to solve the managerial problems of the public sector. Academic activities must be directed to the questions conceming the "reason of existence" and the "object" of the discipline of public administration. As Özen points out, this also brings a question into mind: what is the fundamental prcoccupation of this discipline?(1995: 71). There are two main approaches concerning this question. The first one is a relatively "narrow" approach (Üstüner, 1986: 142) focusing on the "organisational and managerial" dimension of executive organs and/or administrative organisations of the state (McCurdy, 1986,: 1-2, 25). The second one is, however, a "broader, more comprehensive and political" approach focusing on all dimensions of social life (McCurdy, 1986: 1-2, 31; Üstüner, 1986: 143). Despite some modifications made in the 1960 s with the effect of developing a political perspective, the first approach, as Özen emphasised, was dominant in the universal public administration literature of the time and this approach which stems from "functionalist" paradigm reinforces the identity crisis of public administration (1995: 72-73; 90).

With the aim of creating an independent discipline and with the effect of the functionalist paradigm, the field of study of the discipline of public administration was restricted to the "administration" or "bureaucracy" as an operational part of the state, and a broader approach focusing on the "state" in all aspects was neglected. Since public administration was scen as a locomotive of national development especially after the Second World War, studying this subject was considered to be highly prestigious preoccupation but the aim and methodology of the discipline was not questioned enough. 
This was, in fact, in harmony with the narrow organisational and managerial approach. Thus this feature to some extent facilitated the move to a more "managerial" approach later on in this field. As a matter of fact, with the advent of globalisation and liberalisation processes in the 1980s and 1990s, universal market mechanisms have replaced the bureaucratic mechanisms. The focus of interest has shifted to the economic and financial aspects of the public sector. The creation of more efficient and effective organisations and mechanisms in the public sector has become the main concern. Public administration as a discipline and practice could not completely cover and absorb this development (see Üstüner, 1992, 1995; and Ayman-Güler, 1994: 3-4, 7, 17, 1995: 4). As a matter of fact, the tern "public sector management" is now in common usage to refer to the new economic and financial concern in this field. We should point out that this is also a limited concern for scholars studying the public sector as the political, economic and managerial aspects of the public sector are closely interlinked. Emphasising its managerial aspect and not considering the difference between public and private sectors is a common and dangerous mistake. Similarly, identifying the efforts that revicw and value its managerial aspect with the hegemony of the New Right ideology and then emphasising only its political aspect (its close ties with political science) is also a narrow approach (for this position, see Ayman-Güler, 1994, 1995). Actually, Güler admits the danger of this approach especially in terms of the relationship between public administration and political science disciplines. She sees that excessive reliance on political scienca may confuse rather than clarify the question of what the actual field of study of public administration is (Ayman-Güler, 1995: 3). However, her orthodox/radical stand leads Ayman-Güler to claim that the only way of salvation for public administration is it:s redefinition as the "discipline of the state science" that embraces not only the central administrative organisation, but the phenomenon of the state with all dimensions and institutions $(1994: 4-5,19 ; 1995: 4)$. It is obvious that this raises a question in one's mind as to what the difference between public administration and political science actually is. It also gives rise to the danger that public administration may lose its distinctiveness in the family of political sciences.

(12) It is possible to see NPM as a neutral approach or as a part of the attempt to "depoliticise" public policy provision. The appeal of NPM lies its promise to go beyond politics (whether party, interest group or organisational micro-politics) and produce rational and efficient decisions about the deployment of resources rather than produce the political discourse about public policies. The "depoliticisation" associated with NPM is actually being driven by one of the most "politicised" restructurings of the national states during this century, especially in the U.K. Therefore, it may be more accurate to argue that NPM has in certain instances politicised rather than depoliticised public servicc issues (sce Clarke, Cochrane and McLaughlin, 1994b: 231, 232).

(13) For some evidence which was supposed to be signs of a welfare backlash in the U.K., see Golding and Middleton (1982) and the surveys of the Institute of Economic Affairs during 1970s. For negative public perception of public services in the U.S., see the Volcker Commision(1990). From various studies, some scholars discovered a similar erosion of public confidence in government and the public service in other Western countries. Sec Mahler and Katz (1988: 48) and Wilenski (1988: 213-215). For contrary results, especially in welfare services, see Taylor-Gooby $(1985,1989,1991)$; Smith (1987); Alber (1988); and British Social Attitudes Surveys after 1983. 
(14) See Pierson (1991: Chp. 2 and 3); Newman and Clarke (1994: 26); Taylor (1993); Williams (1993).

(15) Some authors argue that the transformative power of NPM has been profoundly effective in dismantling the "old consensus" on the traditional model but considerably less effective in producing a new stable setulement or a singular future (see Clarke, Cochrane and McLaughlin, 1994b: 230, 239-240).

\section{References}

ABERBACH, J. D., R. D. PUTNAM, and B. A. ROCKMAN (1981). Bureaucrats\&Politicians in Western Democracies, (Mass.: Harvard University Press).

AKSOY, S (1995), "Yeni Sağ ve Kamu Yönctimi" in Kamu Yönetimi Disiplini Sempozyumu Bildirileri, Vol. II, (Ankara: TODAİE).

ALBER, J. (1988), "Continuities and Changes in the Idea of the Welfare State", Politics and Society, Vol. 16, No. 4.

ALliSON, G. T. (1979), Public and Private Management: Are They Fundamentally Alike in All Unimportant Respects?, Paper to Public Management Research Conference, (Washington D.C. : Brookings Institution); reprinted in Perry and Kracmer (1983).

APPlebY, P. H. (1949). Policy and Administration, (University, Ala.: University of Alabama Press).

ARGYRIS, C. (1990). Overcoming Organizational Defences: Facilitating Organizational Learning, (Needham Heights, Mass.: Allyn\&Bacon).

AUCOIN, P. (1988), "Contraction, Managerialism and Decentralisation in Canadian Government", Governance, Vol. 1, No. 2.

AUCOIN, P. (1990), "Administrative Reform in Public Management: Paradigms, Principles, Paradoxes and Pendulums", Governance, Vol. 3, No. 2.

AUCOIN, P. (1991), " The Politics and Management of Restraint Budgeting", in A. Blais and $S$. Dion (eds.), The Budget-Maximizing Bureaucrat: Appraisals and Evidence, (Pittsburgh, Pa.: University Pittsburgh Press).

AYMAN-GÜLER, B. (1994), "Nesnesini Arayan Disiplin: Kamu Yönctimi", Amme Idaresi Dergisi, Vol. 27, No. 4.

AYMAN-GÜLER, B (1995), "Scmpozyum Genel Raporu" in Kamu Yönetimi Disiplini Sempozyumu Bildirileri, (Ankara: TODAIE).

AYMAN-GÜler, B. (1996). Yeni Sağ ve Devletin Değişimi: Yapısal Uyarlama Politikaları, (Ankara: TODAIE). 
AYMAN-GÜlER, B. (1997), "21. Yüzyılda Nasıl Bir Kamu Yönetimi?", 21. Yüzyılda Nasıl Bir Kamu Yönetimi Sempozyumu. Açılıs Bildirisi, (Ankara: TODAIE).

BARZELAY M. and B.J. ARMANJANI (1992). Breaking through Bureaucracy: A New Vision for Managing in Government, (Berkeley, Ca: University of California Press).

BAY, C. (1972), "Thoughts on the Purposes of Political Science Education" in G. J. Graham and G. W. Carey (eds.), The Post-Behavioral Era: Perspectives on Political Science, (New York: David McKay).

BELlONE, C. J. (ed.) (1980). Organisation Theory and the New Public Administration, (Boston: Allyn\&Bacon).

BEYER, J. M., J. M. STEVENS and H. M. TRICE (1983)," The Implementing Organization: Exploring the Black Box in Public Policy Research" in R. C. Hall and R. E. Quinn (eds.), Organization Theory and Public Policy, (Beverly Hills: Sage).

BHATTACHARYA, M. (1990), "Recent Advances in the Discipline of Public Administration", The Indian Journal of Public Administration, Vol. XXXVI, No. 1.

BLUNKETT, D. and K. JACKSON (1987). Democracy in Crisis: The Town Halls Respond, (London: Hogarth Press).

BORINS, S. (1994). Government in Transition: A New Paradigm in Public Administration, A Report on the Inaugural Conference of the Commenwealth Association for Public Administration and Management, (Toronto: CAPAM).

BOSTON, J. (1987), " Transforming New Zealand's Public Sector: Labour's Quest for Improved Efficiency and Accountability", Public Administration, Vol. 65, Winter Issue.

BOSTON, J. (ed.) (1991). Reshaping the State: New Zealand's Bureuacratic Revolution, (Auckland: Oxford Universily Press).

BOSTON, J. (ed.) (1996). Public Management: The New Zealand Model, (Auckland: Oxford University Press).

BOUCKaerT, G. (199()), "The History of the Productivity Movement", Public Productivity\&Management Review, Vol. 14.

BOUCKAERT, G. and A. HALACHMI (1995), "Introduction: The Challenges of Management in a Changing World" in A. Halachmi and G. Bouckaert (eds.), The Enduring Challenges in Public Management, (San Fransisco, Cal.: Jossey-Bass). 
BOYLE, R. (1992), "Civil Service Management Trends: Challenges for the 1990s", Administration, (Journal of the Institute of Public Administration of Ireland), Vol. 39, No. 1.

BOZEMAN, B. (1988), "Exploring the Limits of Public and Private Sectors: Sector Boundaries as Maginot Line, Public Administration Review, Vol. 48, No. 2.

BOZEMAN, B. (ed.), (1993). Public Management: The State of Art, (San Fransisco, Cal.: Jossey-Bass).

BOZEMAN, B. and STRAuSmanN (eds.) (1984). New Directions in Public Administration, (Montcrey, Cal.: Brooks/Cole).

BUTLER, Sir R. (1992), "The New Public Management: The Contribution of Whitehall and Academia", Public Policy and Administration, Vol. 7, No. 3.

BUTler, Sir R. (1994), "Reinventing British Government", Public Administration, Vol. 72, No. 1.

CAIDEN, G. E. (1981), "Administrative Reform" in G. R. Curnow and R. L. Wettenhall (eds.). Understanding Public Administration, (Sydney: Allen and Unwin).

CAIDEN, G. E. (1982). Public Administration, (2nd ed.), (Pacific Palisades: Palisades Pub.).

CAIDEN, G. E. (1991). Administrative Reform Comes of Age, (New York: Walter de Gruyter).

CAMPBELL, C. (1995), "Does Reinvention Need Reinvention? Lessons from Truncated Managerialism in Britain", Governance, Vol. 8, No. 4.

CAMPBELL, C. and B. G. PETERS, (1988), "The Politics-Administration Dichotomy: Death or Merely Change?", Governance, Vol. 1, No. 1.

CARROLL, J. D., A. L. FRITSCHLER, and B. L. R. SMITH (1985), "Supply-Side Management in the Reagan Administration", Public Administration Review, Vol. 45, No. 6.

CHANDLER, J. A. (1988), "Public Administration or Public Management", Teaching Public Administration, Vol. VIII, No.1.

CHANDLER, J. A. (1991), "Public Administration: A Discipline in Decline", Teaching Public Administration, Vol. XI, No. 2.

CHRISTENSEN, J. G. (1988), "Withdrawal of Government: A Critical Survey of an Administrative Problem in its Political Context", International Review of Administrative Science, Vol. 54, No.1. 
CLARKE, J., A. COCHRANE, and E. MCLAUGHLIN (1994a), "Introduction: Why Management Matters" in J. Clarke, A. Cochrane, and E. McLaughlin (eds.), Managing Social Policy, (London: Sage).

CLARKE, J., A. COCFrRANE, and E. MCLAUGHLIN (1994b), "Mission Accomplished or Unfinished Business? The Impact of Managerialization" in J. Clarke, A. Cochrane, and E. McLaughlin (eds.), Managing Social Policy, (London: Sage).

Clarke, M. and J. STEWART (1986). The Public Service Orientation: Developing the Approach, (Luton: Local Government Training Board).

CROZIER, M. (1964). The Bureaucratic Phenomenon, (Chicago: University of Chicago).

COURSEY, D. and B. BOZEMAN (1990), "Decision-Making in Public and Private Organizations: A Test of Alternative Concepts of "Publicness", Public Administrative Review, Vol. 50, No. 5.

DENHARDT, R. B. (1582), "Public Administration: Sub-Ficld? Profession? Discipline?", American Review of Public Administration, Vol. 16, No.1.

DOIG, J. W. (1983), "If I See a Murderous Fellow Sharpening a Knife Cleverly...: The Wilsonian Dichotomy and the Public Authority Tradition", Public Administration Review, Vol. 43, No. 3.

DOWNS, A. (1967). Inside Bureaucracy, (Boston: Little, Brown).

DRUCKER, P. (1986). The Frontiers of Management, (New York: Dutton).

DUNLEAVY, P. (1982), "Is There a Radical Approach to Public Administration", Public Administration, Vol. 60, Summer Issue.

DUNLEAVY, P. (1991). Democracy, Bureaucracy\&Public Choice: Economic Explanations in Political Science, (Hemel Hempstead, Hert.: Harvester Wheatsheaf).

DUNLEAVY, P. (1994), "The Globalization of Public Services Production: Can Government be 'Best in World'?", Public Policy and Administration, Vol. 9, No. 2.

DUNLEAVY, P. and C. HOOD (1994), "From Old Public Administration to New Public Management", Public Money\&Management, Vol. 14, No. 3.

DUNSIRE, A. (1995), "Administrative Theory in the 1980s: a Viewpoint", Public Administration, Vol. 73, Spring Issue. 
DUNSIRE, A. and C. HOOD (1989). Cutback Management in Public Bureaucracies: Popular Theories and Observed Outcomes in Whitehall, (Cambridge: Cambridge University Press).

ELCOCK, H. (1991). Change\&Decay? Public Administration in the 1980s, (Harlow, Essex: Longman).

ELCOCK H. (1995), "The Fallacies of Management", Public Policy and Administration, Vol. 10, No. 1.

ELIASSEN, K. A and J. KOOIMAN (1987), "Introduction" in J. Kooiman and K. A. Eliassen (eds.) Managing Public Organizations: Lessons from Contemporary European Experience, (London: Sage).

ELIASSEN, K. A and J. KOOIMAN (1993). Managing Public Organizations: Lessons from Contemporary European Experience, (2nd. ed.) (London: Sage).

EMMERT, M. A., M. CROW, and R. F. SHANGRAW, Jr. (1993), "Public Management in the Future: Post-Orthodoxy and Organization Design" in B. Bozeman (ed.), Public Management: The State of Art, (San Fransisco, Cal.: Jossey-Bass).

ERGUN, T. (1995), "Kamu Yönetiminin Gelişimine Kısa Bir Bakış: Yeni Arayıslar ve Gerçekler" Açılıs Bildirisi, Kamu Yönetimi Sempozyumu Disiplini Bildirileri, Vol. I, (Ankara: TODAIE).

FARAZMAND, A. (1994), "The New World Order and Global Public Administration: A Critical Essay" in J. C. Garcia-Zamor and R. Khator (eds.), Public Administration in the Global Village, (Westport, CT: Praeger).

FARNHAM, D. and S. HORTON (1996a), "The Political Economy of Public Sector Change" in D. Farnham and S. Horton (eds.), Managing the New Public Services, (2nd. ed.), (London: Macmillan).

FARNHAM, D. and S. HORTON (1996b), "Managing Private and Public Organisations" in D. Farnham and S. Horton (eds.), Managing the New Public Services, (2nd. ed.), (London: Macmillan).

FARNHAM, D. and S. HORTON (1996c), "Public Service Managerialism: A Review and Evaluation" in D. Farnham and S. Horton (eds.), Managing the New Public Services, (2nd ed.), (London: Macmillan).

FARNHAM, D. and S.' HORTON (eds.) (1996d). Managing the New Public Services, (2nd. ed.), (London: Macmillan).

FLYNN, N (1993). Public Sector Management, (2nd ed.), (Hemel Hempstead, Hert.: Harvester Wheatsheaf). 
FOSTER, C.D. and F.J. F'LOWDEN (1996). The State Under Stress: Can the Hollow State be Good "Government?, (Buckingham: Open University Press).

FOX, C. J. and H. T. MJlleR (1995). Postmodern Public Administration: Toward Discourse, (London: Sage).

FREDERICKSON, H. G. (1990). New Public Administration, (University of Alabama Press).

FREDERICKSON, H. G. (1991), "Toward a Theory of the Public for Public Administration", Administration\&Society, Vol. 22, No. 4.

FRIEDRICH, C. J. (1940), "Public Policy and the Nature of Administrative Responsibility" in C. J. Fricdrich and E. S. Mason (eds.), Public Policy, (Cambridge, MA.: Harvard University Press).

FULTON, LORD (1968). The Report of the Committee on the Civil Service, (London: HMSO).

GARSON, G. D. and E. S. OVERMAN (1983). Public Management Research in the United States, (New York: Praeger).

GAUS, J. M. (1950), "Trends in the Theory of Public Administration", Public Administration Review, Vol. 10.

GOLDING R. and S. MIDDLETON (1982). Images of Welfare: Press and Public Attitudes to Poverty, (Oxford: Martin Robertson).

GOLEMBIEWSKI, R. T. (1974), " 'Maintenance' and 'Task' as Central Challenges in Public Administration", Public Administration Review, Vol. 34, No. 2.

GOLEMBIEWSKI, R. T. (1977). Public Administration as a Developing Discipline: Part 1-Perspective on Past and Present, (New York: Marcel and Dekker).

GOODNOW, F. J. (1900). Politics and Administration, (New York: Macmillan).

GOOdSEll, C. T. (1994). The Case for Bureaucracy: A Public Administration Polemic, (3rd ed.), (Chatham, N.J.: Chatham).

GORE, A. (1993). From Red Tape to Results: Creating a Government that Works Better\&Costs Less, Report of the National Performance Review, (New York: Time Books/Random House).

GORMLEY, W. T. (1989). Taming the Bureaucracy: Muscles, Prayers, and Other Strategies, (Princcton, N. J.: Princeton University Press). 
GRAY A. and B. JENKINS (1995), "From Public Administration to Public Management: Reassesing a Revolution?", Public Administration, Vol. 73, Spring Issue.

GREENWOOD, J. and D. WILSON (1988), "British Public Administration: The Beginning of the End?", Teaching Politics, Vol. 17, No. 3.

GREENWOOD, J. and D. WILSON (1989). Public Administration in Britain Today, (2nd ed.), (London: Unwin Hyman).

GREEN, R. T. and L. F. KELLER, and G. L. WAMSLEY, (1993), " Reconstituting a Profession for American Public Administration", Public Administration Review, Vol. 53, No. 6.

GULICK, L. and L. URWICK (eds.) (1937). Papers on the Science of Administration, (New York: Institute of Public Administration).

GUNN, L. (1987), "Perspectives on Public Management", J. Kooiman and K. A. Eliassen (eds.), Managing Public Organizations, (London: Sage).

GUNN, L. (1988), "Public Management: A Third Approach", Public Money\&Management, Vol. 8, No.1.

GYFORD, J. (1985). Politics of Local Socialism, (London: Allen\&Unwin).

HAQUE, M. S. (1996a), "The Intellectual Crisis in Public Administration in the Current Epoch of Privatization", Administration\&Society, Vol. 27, No, 4.

HAQUE, M. S. (1996b), "Public Service Under Challenge in the Age of Privatization", Governance, Vol. 9, No. 2.

HARMON, M. M. (1981). Action Theory for Public Administration, (New York: Longman).

HARRIS, P. (1990). Foundations of Public Administration: A Comparative Approach, (Hong Kong: Hong Kong University Press).

HART, D. K. and C. D. WASDEN (1990), " Two Roads Diverged in a Yellow Wood: Public Administration, the Management Orthodoxy, and Civic Humanism", International Journal of Public Administration, Vol. 13, No. 6.

HENRY, N. (1975), "Paradigms of Public Administration", Public Administration Review, Vol. 35, No. 4.

HENRY, N. (1989). Public Administration and Public Affairs, (4th ed.), (Englewood Cliffs, N.J.: Prentice Hall).

HESELTINE, M. (1980), "Ministers and Management in Whitchall," Management Services in Government, U.K., 35. 
HILL, L. B. (ed.) (1992). The State of Public Bureaucracy, (New York: Armonk).

HOGGeTT, P. (1991), "A New Management in the Public Sector?", Policy and Politics, Vol. 19, No. 4.

HOGGETT, P. (1996), "New Modes of Control in the Public Service", Public Administration, Vol. 74, Spring Issue.

HOGGETT, M. and R. HAMBLETON (eds.) (1987). Decentralisation and Democracy, University of Bristol-SAUS Occasional Paper, No. 26.

HOLMES, M. (1992), "Public Sector Management Reform: Convergence or Divergence?", Governance, Vol. 5, No. 4.

HOLMES, M. and D. SHAND (1995), "Management Reform: Some Practitioner Perspectives on the Past Ten Years", Governance, Vol. 8, No. 4.

HOLTHAM, C. (1992), "Key Challenges for Public Services Delivery" in L. Willcocks and J. Harrow (cds.), Rediscovering Public Services Management, (London: Mc Graw-Hill).

HOOD, C. (1987), "Public Administration" in V. Bogdanor (ed.), The Blackwell Encyclopedia of Political Institutions, (Oxford: Basil Blackwell).

HOOD, C. (1989), "Public Administration and Public Policy: Intellectual Challenges for the 1990s", Australian Journal of Public Administration, Vol. 48, No. 4 .

HOOD, C. (1990a), "Public: Administration: Lost an Empire, Not Yet Found a Role?" in A. Leftwich (ed.), New Developments in Political Science: An International Review of Achievements and Prospects, (Aldershot, Hants: Edwar Elgar).

HOOD, C. (1990b), "Beyond the Public Bureaucracy State? Public Administration in the 1990s", Inaugural Lecture, London School of Economics, January 16, 1990.

HOOD, C. (1991), "A Public Management for All Seasons", Public Administration, Vol. 69, Spring Issue.

HOOD, C. (1995a), "Contemporary Public Management: A New Global Paradigm", Public Policy and Administration, Vol. 10, No. 2.

HOOD, C. (1995b), "Emerging Issues in Public Administration", Public Administration, Vol. 73, Spring Issue.

HOOD, C. (1996), "Beyond 'Progressivism': A New 'Global Paradigm' in Public Management?", International Journal of Public Administration, Vol. 19, No. 2. 
HOPWOOD, A.G. and C. TOMKINS (eds.) (1984). Issues in Public Sector Accounting, (Oxford: Philip Allen).

HORTON, S. (1996), "The Civil Service" in D. Farnham and S. Horton (eds.), Managing the New Public Services, (2nd ed.), (London: Macmillan).

HOUSTON, D. J. (1993), "Search for Identity: The Impact of the 'Great Books' in Public Administration", International Journal of Public Administration, Vol. 16, No. 5.

HUGHES, O. E. (1994). Public Management\&Administration: An Introduction, (London: The MacMillan).

HUNT, M. (1990), "Undergraduate Degree in Public Sector Management", Teaching Public Administration, Vol. X, No. 2.

HUSSARD, J. and M. PEKER (eds.) (1993). Postmodernism and Organizations, (London: Sage).

ILO (1995), Impact of Structural Adjustment in the Public Services, (Gencva: International Labour Office).

INGRAHAM, P. W. (1997), "Play It Again, Sam; It's Still Not Right: Searching for the Right Notes in Administrative Reform", Public Administration Review, Vol. 57, No. 4.

INGRAHAM, P. W. and C. R. BAN (1986), "Models of Public Management: Are They Useful to Public Managers in the 1980s?", Public Administration Review, Vol. 46, No. 2.

ISAAC-HENRY, K. (1993), "Development and Change in the Public Sector" in K. Isaac-Henry, C. Painter, and C. Barnes (eds.), Management in the Public Sector: Challenge and Change, (London: Chapman\&Hall).

ISAAC-HENRY, K., C. PAINTER, and C. BARNES (eds.) (1993). Management in the Public Sector: Challenge and Change, (London: Chapman\&Hall).

JACKSON, P. M. (1982). The Political Economy of Bureaucracy, (Oxford: Philip Allan).

JACKSON, P. M. (1988), "Management Techniques in the U.K. Public Sector", International Review of Administrative Sciences, Vol. 54.

JACKSON, P. M. (1990), "Public Choice and Public Sector Management", Public Money and Management, Vol. 10, No. 4.

JACKSON, P. M. (1994), "The New Public Sector Management: Surrogate Competition and Contracting Out" in P. M. Jackson and C. M. Price (eds.), Privatisation and Regulation: A Review of the Issues, (Harlow, Essex: Longman). 
JOHNSON, E. (1993), "The Challenge to the Public Sector: Changing Politics and Ideologies" in K. Isaac-Henry, C. Painter, and C. Barnes (eds.), Management in the Public Sector: Challenge and Change, (London: Chapman\&Hall).

JOHNSON, N. (1990). Restructuring the Welfare State, (London: Harvester Wheatshcaf).

JOHNSTON, J. and G. CALLENDER (1997), "Vulnerable Governments: Inadvertent DeSkilling in the New Global Economic and Managerialist Paradigm?", International Review of Administrative Sciences, Vol. 63.

JONES, G. W. (1989), "A Revolution in Whitehall? Changes in British Central Government since 1979", West European Politics, Vol. 12.

KASS, H. D. and B. L. CATRON (eds.) (1990), Images and Identities in Public Administration, (London: Sage).

KEATING, M. (1988), "Quo Vadis? Challenges of Public Administration", Australian Journal of Public Administration, Vol. 48.

KEATING, M (1991), "Management of the Public Scctor" in J. Llewellyn and S. J. Potter (eds.), Economic Policies for the 1990s, (Oxford: Blackwell).

KELMAN, S. (1991), " The Prescriptive Message', The Public Administration of James Q. Wilson: A Symposium on Burcaucracy", Public Administration Review, Vol. 51, No. 3.

KERNAGHAN, K. (1993) "Reshaping Government: the Post-Bureaucratic Paradigm", Canadian Public Administration, Vol. 36, No.4.

KHUN, T. (1964). The Structure of Scientific'Revolutions, (Chicago: University of Chicago Press).

KHUN, T. (1970), "Reflections on My Critics" in I. Lakotas and A. Musgrave (eds.), Criticism and the Growth of Knowledge, (New York: Cambridge University Press).

KINGDOM, J. (1986a), "Public Administration: Defining the Discipline-Part I", Teaching Public Administration, Vol. VI, No. 1.

KINGDOM, J. (1986b), "Public Administration: Defining the Discipline-Part II", Teaching Public Administration, Vol. VI, No. 2.

KINGDOM, J. (1990), "Public Administration or Public Implementation-A Discipline in Crisis", Public Policy and Administration, Vol. 5, No. 2.

KINGSLEY, G. (1997), "Reflecting on Reform and the Scope of Public Administration", Public Administration Review, Vol. 57, No. 2. 
KIRKPATRICK, I and M. MARTINEZ LUCIO (1996), "Introduction: The Contract State and the Future of Public Management", Public Administration, Vol. 74, Spring Issue.

KOOIMAN, J. (ed.) (1993). Modern Governance: New Government-Society Interactions, (London: Sage).

KOOIMAN, J and K. A. ELIASSEN (1987). Managing Public Organizations: Lessons from Contemporary European Experience, (London: Sage).

KOUZMIN, A., J. DIXON, and J. WILSON (1995), "Commercializing 'Washminster' in Australia: What Lessons?", Public Money\&Management, Vol. 15, No. 2.

LAN, Z. and D. V. ROSENBLOOM (1992), "Editorial", Public Administration Review, Vol. 52, No. 6.

iLAWTON, A. and A. ROSE (1994). Organisation and Management in the Public Sector, (2nd ed.), (London: Pitman Publishing).

LEVINE, C. H. (1979), Public Management: First Approximations", International Journal of Public Administrations Vol. 1, No. 4.

LLEWELlyn, J. and S. J. POTTER (1991). Economic Policies for the 1990s, (Oxford: Blackwell).

LONG, N. (1954), "Public Policy and Administration: The Goals of Rationality and Responsibility", Public Administration Review, Vol. 14, No. 1.

LONG, N. (1981), "The S.E.S. and the Public Interest", Public Administration Review, Vol. 41., No. 3

LOVRICH, N. P. Jr. (1985), "Contending Paradigms in Public Administration": A Sign of Crisis or Intellectual Vitality?", Administration\&Society, Vol. 17, No. 3.

LYNN, L. E. Jr. (1987). Managing Public Policy, (Boston: Little, Brown).

LYNN, L. E. Jr. (1996). Public Management as Art, Science, and Profession, (Chatham, N. J.: Chatham House).

LYNN, N. B. and A. WILDAVSKY (eds.) (1990). Public Administration: The State of the Discipline, (Chatham, N. J.: Chatham House).

McCURDY, H. E. (1986), Public Administration: A Bibliographic Guide to the Literature, (New York: Marcel Dckker).

McKEWITT, D. and A. LAWTON (ed.) (1994). Public Sector Management: Theory, Critique\&Practice, (London: Sage-Open University). 
McSWITE, O. C. (1997), "Postmodernism and Public Administration's Identity Crisis", (Book Review), Public Administration Review, Vol. 55, No. 2.

MAHLER, V. A. and C. J. KATZ (1988). "Social Benefits in Advanced Capitalist Countries: A Crcss-National Assessment", Comparative Politics, Vol. 21, No.1.

MAJOR, J. (1989). Public Service Management: The Revolution in Progress, (London: The Audit Commission).

MARANTO, R. and D. SCHULTZ (1991). A Short History of the United States Civil Service, (Lanham, MD.: University Press of America).

MARX, F. M. (1946). Elements of Public Administration, (New York: Prentice Hall).

MASCARENHAS, R. C. (1990). "Reform of the Public Service in Australia and New Zealand", Governance, Vol. 3, No. 1.

MASCARENHAS, R. C. (1993), "Building an Enterprise Culture in the Public Sector: Reform of the Public Sector in Australia, Britain, and New Zealand", Public Administration Review, Vol. 53, No. 4.

MASSEY, A. (1993). Managing the Public Sector: A Comparative Analysis of the United Kingdom and the United States, (Aldershot: Edward Elgar).

MERINO, M. (1996), "From a Discipline Without a Subject to a Subject Without a Discipline: Public Administration and Public Policies from an Institutional Perspective", International Journal of Public Administration, Vol. 19, No. 9.

MERTON, R. K. (1968). Social Theory and Social Structure, (3rd ed.), (New York: Free Press).

METCALFE, L. (1993), "Conviction Politics and Dynamic Conservatism: Mrs. Thatcher's Managerial Revolution", International Political Science Review, Vol. 14, No. 4.

METCALFE, L. and S. RICHARDS (1990). Improving Public Management, (2nd ed.), (London: Sage-European Institute of Public Administration).

MIDWINTER, A. F. (1990), "Editorial: What New Managerialism?", Public Policy and Administration, Vol. 5, No. 1.

MINTZBERG, H. (1979). The Structuring Organizations, (Englewood Cliffs, N. J.: Prentice-Hall).

MINTZBERG, H. (1983). Structures in Fives, (Englewood Cliffs, N. J.: PrenticeHall). 
MUHAMMAD, F. (1988), "Public Administration: Prevailing Perceptions and Priorities", International Review of Administrative Sciences, Vol. 54, No. 1 .

NEWMAN, J. and J. CLARKE (1994), "Going About Our Business? The Managerialization of Public Services" in J. Clarke, A. Cochrane, and E. McLaughlin (eds.), Managing Soical Policy, (London: Sage).

NEWLAND, C. A. (1983), "The Reagan Presidency: Limited Government and Political Administration", Public Administration Review, Vol. 43, No. 1.

NISKANEN, W. A. (1971). Bureaucracy and Representative Government, (Chicago, Ill.: Aldine-Atherton).

OECD (1990). Financing Public Expenditures through User Charges, Occasional Papers on Public Management, (Paris:OECD).

OECD (1991). Serving the Economy Better, Occasional Paper on Public Management, (Paris: OECD).

OECD (1993). Public Management: OECD Country Profiles, (Paris: OECD).

OECD (1995). Governance in Transition: Public Management Reforms in OECD Countries, (Paris: Puma-OECD).

ORMOND, D. (1993), "Improving Government Performance", The OECD Observer, No. 184 , October/November Issue.

OSBORNE, D. and T. GAEBLER (1992). Reinventing Government: How the Entrepreneurial Spirit is Transforming the Public Sector, (Reading, Mass:: Addison-Wesley).

OSTROM, V. (1974). The Intellectual Crisis in American Public Administration, (rev. ed.), (Tuscaloosa: University of Alabama Press).

OVERMAN, E. and K. BOYD (1994), "Best Practice Research and Post-Bureaucratic Reform", Journal of Public Administration Research and Theory, Vol. 4.

ÖMÜRGÖNÜLSEN, U. (1995), An Analysis of the Government's Strategy Concerning the Staff Cutbacks in the Turkish Civil Service: Cutback or Restraint, Discussion Paper in Public Sector Economics, Faculty of Social Sciences, Public Sector Economics Research Centre, Leicester University, U.K., No. 95/4.

ÖZEN, Ş. (1995), "Kamu Yönetimi Yazınımız ve Örgütler-Yönetim Çalışma Alanı: Tehlikeli Ilişkiler" in Kamu Yönetimi Disiplini Sempozyumu Bildirileri, Vol. I, (Ankara: TODAIE). 
PAINTER, C. (1993), "Marıaing Change in the Public Sector" in K. Isaac-Henry, C. Painter, and C. Barnes (eds.), Management in the Public Sector: Challenge and Change, (London: Chapman\&Hall).

PEAT MARWICK (1986). Current Issues in Public Sector Management, (London: Peat Marwick).

PERRY, J. L. (1993). "Public Management Theory: What Is It? What Should It Be?" in B. Bozeman (ed.), Public Management: The State of Art, (San Fransisco, Cal.: Josisey-Bass).

PERRY, J. L. and K. L. KRAEMER (1983). Public Management: Public and Private Perspectives, (Palo Alto, Cal.: Mayfield).

PETERS, B. G. (1989). The Politics of Bureaucracy, (3rd ed.), (London: Longman).

PETERS, B. G. (1991), "Government Reform and Reorganization in an Era of Retrenchment and Conviction Politics" in A. Farazmand (ed.), Handbook of Comparative and Development Public Administration, (New York: Marcel Dekker).

PETERS, B. G. and D. J. SAVOIE (1994), "Civil Service Reform: Misdiagnosing the Patient", Public Administration Review, Vol. 54, No. 5.

PETERS, T (1989). Thriving on Chaos, (London: Pan).

PETERS, T. and R. H. WATERMAN Jr. (1982). In Search of Excellence: Lessons from America's Best-Run Companies, (New York: Harper\&Row).

PETERS, T. and N. AUSTIN (1985). A Passion for Excellence: The Leadership Difference, (London: Fortana).

PFIFFNER, J. P. (1987), "Political Appointees and Career Executives: The DemocracyBureaucracy Nexus in the Century", Public Administration Review, Vol. 47 , No. 1 .

PIERSON, C. (1991). Beyond the Welfare State: The New Political Economy of Welfare, (Cambridge: Polity Press).

POLLITT, C. (1993). Managerialism and Public Services, (2nd. ed.), (Oxford: Blackwell).

POLLITT, C. (1996), "Antistatist Reforms and New Administrative Directions: Public Administration in the United Kingdom", Public Administration Review, Vol. 56, No. 1. 
POWER, M. and R. LAUGHLIN (1992), "Critical Theory and Accounting" in N. Alveson and H. Willmott (eds.), Critical Management Studies, (london: Sage).

PROKOPENKO, J. (1989). Management Implications of Structural Adjustment, (Geneva: ILO).

RAINEY, H. G. (1990), "Public Management: Recent Developments and Current Prospects" in N. B. Lynn and a. Wildavsky (eds.), Public Administration: The State of the Discipline, (Chatham, N. J.: Chatham House).

RAINEY, H. G. (1991). Understanding and Managing Public Organizations, (San Fransisco: Jossey-Bass).

RANSON, S. and J. STEWART (1994). Management for the Public Domain: Enabling the Learning Soicety, (New York: St. Martin's Press).

RHODES, R. A. W. (1991), "Theory and Methods in British Public Administration: The View from Political Science", Political Studies, Vol. XXXIX.

RHODES, R. A. W. (1996), "From Institutions to Dogma: Tradition, Eclecticism, and Ideology in the Study of British Public Administration", Public Administration Review, Vol. 56, No. 6.

RHODES et al. (1995), "The State of Public Administration: A Professional History, 1970-1995", Public Administration, Vol. 73, Spring Issue.

RIDLEY, F. F. (1996), "The New Public Management in Europe: Comparative Perspectives", Public Policy and Administration, Vol. 11, No. 1.

ROSENBlOOM, D. H. (1989). Public Administration: Understanding Management, Politics, and Law in the Public Sector, (2nd ed.), (New York : Random House).

ROURKe, F. E. (1984). Bureaucracy, Politics, and Public Policy, (Boston: Liule, Brown).

RUTGERS, M. R. (1997), "Beyond Woodrow Wilson: The Identity of the Study of Public Administration in Historical Perspective", Administration\&Society, Vol. 29, No. 3.

SAVOIE, D. J. (1994). Thatcher, Reagan, Mulroney: In Search of a New Bureaucracy, (Pittsburgh, PA.: University of Pittsburgh Press).

SCHWARTZ, H. (1994), "Small States in Big Trouble", World Politics, Vol. 46, No. 4.

SCOTT, G. P., P. BUSHNELL, and N. SALLEE (1990), "Reform of the Core Public Sector: New Zealand Experience", Governance, Vol. 3. 
SELF, P. (1993). Government by the Market?, (London: Macmillan).

SHICK, A. (1975), "The Trauma of Politics: Public Administration in the Sixties" in F. C. Mosher (ed.), American Public Administration: Past, Present, Future, (Syracuse: Maxwell School of Citizenship and Public Affairs and the National Association of Schools of Public Affairs and Administration).

SHICK, A. (1990), "Budgeling for Results: Recent Developments in Five Industrialised Countries", Public Administration Review, Vol. No. 1.

SMITH, T.W. (1987), "The Polls - A Report: The Welfare State in Crossnational Perspective", Public Opinion Quarterly, Vol. 51.

STEWART, J. D. (1983). Local Government: The Freedom of Local Choice, (London: Allen and Unwin).

STEWART, J. and S. RANSON (1988), "Management in the Public Domain", Public Money\&Management, Vol. 8, No. 1-2.

STEWART, J. and K. WAI.SH (1992), "Change in the Management of Public Services", Public Administration, Vol. 70, Winter Issue.

STILlMAN, R. J. (1991). Preface to Public Administration: A Search for Themes and Direction, (New York: St. Martin's Press).

STILLMAN, R. J. (1997), 'American vs. European Public Administration: Does Public Administration Make the Modern State, or Does the State Make Public Administration?", Public Administration Review, Vol. 57, No. 4.

ŞAYLAN, G. (1994). Değişim, Küreselleşme ve Devletin Yeni Işlevi, (Ankara: Imge).

SAYLAN, G. (1995), "’oulantzas'ın Devlet Kuramına Katkıları Üzerine Bazı Düşünceler" in Kamu Yönetimi Disiplini Sempozyumu Bildirileri, Vol. I, (Ankara: TODAIE).

ŞAYLAN, G. (1996), "Bağımsız Bir Disiplin Olarak Kamu Yönetimi: Yeni Paradigma Arayışları, Amme İdaresi Dergisi, Vol. 29, No. 3.

TAN, T. (1988), "Kamu Hizmeti, Özelleştirme ve Bürokrasinin Azalulması Üzerine", Türk İdare Dergisi, No. 378.

TAN, T. (1995), "Idarede Yeni Ussallık Arayışları ve Hukuk" in Kamu Yönetimi Disiplini Sempozyumu Bildirileri, Vol. II, (Ankara: TODAIE).

TAYLOR, G. (1993), "Challenges from the Margins" in J. Clarke (ed.), A Crisis in Care?, (London: Sage).

TAYLOR, I. and G. POPHAM (1989). An Introduction to Public Sector Management, (London: Unwin Hyman). 
TAYLOR-GOOBY, P. (1985). Public Opinion, Ideology and State Welfare, (London: Routledge-Kegan Paul).

TAYLOR-GOOBY, P. (1989), "The Role of State" in R. Jowell, S. Whitherspoon and L. Brook (eds.), British Social Attitudies: Special International Report, (6th ed.), (Albershot, Hants.: SCPR-Gower).

TAYLOR-GOOBY, P. (1991), "Attachment to the Welfare State" in R. Jowell, L. Brook and B. Taylor (cds.), British Social Attitudes, the 8th Report, (Aldrshot, Hants: SCPR-Gower).

TAYLOR-GOOBY, P. and R. LAWSON (eds.) (1993). Markets and Managers, (Buckingham: Open University Press).

THOMPSON, F. (1997), "Book Review", Journal of Policy Analysis\&Management, Vol. 16, No. 1.

THOMPSON, J. D. (1967). Organizations in Action, (New York: McGraw-Hill).

THOMPSON, P. and D. McHUGH (1995). Work Organisations: A Critical Introduction; (2nd ed.), (London: Macmillan Business).

TREASURY AND CIVIL SERVICE COMMITTEE (The U.K.) (1990). Eight Report of Session 1989-90 Progress in the Next Steps Initiative, HC 481, (London: HMSO).

TULlOCK, G. (1965). The Politics of Bureaucracy, (Washington, D.C.: Public Affairs Press).

TOULMIN, S. E. (1970), "Does the Distinction between Normal and Revolutionary Science Hold Water?" in I. Lakatos and A. Musgrave (eds.), Criticism and the Growth of Knowledge, (Ncw York: Cambridge University Press).

UYSAL-SEZER, B. (1992), "Büyük Devlet-Kü̧̧ük Devlet Tarışması", Amme Idaresi Dergisi, Vol. 25, No. 4.

ÜSTÜNER, Y. (1986), "Kamu Yönetimi Disiplininde Yöntem Sorunları", Türkiye'de Sosyal Bilim Araştırmalarının Gelişimi, S. Atauz (ed.), (Ankara: Türk Sosyal Bilimler Derneği).

ÜSTÜNER, Y. (1992). In Search of an Identity: Considerations on the Theory and the Discipline of Public Administration, Unpublished Ph.D. Thesis, (Ankara: Middle East Technical University).

ÜSTÜNER, Y. (1995), "Kamu Yönetimi Disiplininde Kimlik Bunalımı" in Kamu Yönetimi Disiplini Sempozyumu Bildirileri, Vol. I, (Ankara: TODAtE). 
VECCHIO, R. P. (1991). Organizational Behavior, (2nd ed.), (Chicago, Ill.: Dryden Press).

VENTRISS, C (1987), "Two Critical Issues of American Public Administration: Reflections of a Sympathetic Participant", Administration\&Society, Vol. 19, No. 1.

VENTRISS, C (1989), "Toward a Public Philosophy of Public Administration: A Civic Perspective of the Public", Public Administration Review, Vol. 49, No. 2.

VENTRISS, C (1991), "Contemporary Issues in American Public Administration Education: The Search for an Educational Focus", Public Administration Review, Vol. 51, No. 1.

VOLCKER COMMISSION (National Commission on the Public Service and the Task Force Reports to the National Commission on the Public Service) (1990). Leadership for America: Rebuilding the Publc Service, (Lexington, MA: Lexington Books).

WALDO, D. (1968), "Scope of the Theory of Public Administration" in J. C. Charlesworth (ed.), Theory and Practice of Public Administration: Scope, Objectives, and Methods, (Philadelphia: American Academy of Political and Social Science).

WALDO, D.(1972), "Developments in Public Administration", Annals of the American Academy of Political and Social Sciences, Vol. 404.

WALDO, D. (1975), "Education for Public Administration in the Seventies" in F. C. Mosher (ed.), American Public Administration, (University, Al.: University of Alabama Press).

WALDO, D.(1980). The Enterprise of Public Administration: A Summary View, (Novato, Cal.: Chandler\&Sharp).

WALDO, D.(1990), "A Theory of Public Administration Means in Our Time a Theory of Politics Also" in N. B. Lynn and A. Wildavsky (eds.), Public Administration: The State of the Discipline, (Chatham, N. J.: Chatham House).

WAMSLey, G and R. BACHER (1990). Refounding Public Administration, (California: Sage).

WHITE, J. D. and G. B. ADAMS (eds.) (1994). Research in Public Administration: Reflections on Theory and Practice, (London: Sage-ASPA).

WILENSKI, P. (1988), "Social Change as a Source of Competing Values in Public Administration", Australian Journal of Public Administration, Vol. XLVII, No. 3. 
WILlCOCKS, L. and J. HARROW (eds.) (1992). Rediscovering Public Services Management, (London: McGraw-Hill).

WILliAMS, F. (1993), "Gender, 'Race' and Class in British Welfare Policy" in A: Cochrane and J. Clarke (eds.), Comparing Welfare States, (London: Sage).

WILSON, V. S. (1996), "Public Administration Reform and the 'New Managerialism': A Comparative Assessment of a Fundamental Challenge Confronting Canadian Public Administration", International Journal of Public Administration, Vol 19, No.9.

WILSON, W. (1887), "The Study of Administration", Political Science Quarterly, Vol. 2, No. 1.

WOOD, S. (1989), "New Wave Management", Work, Employment and Society, Vol. 3, No.3.

WORLD BANK (1994) World Development Report 1994: Infrastructure for Development, (New York: Oxford University Press).

WORLD BANK (1995). Bureaucrats in Business: The Economics and Politics of Government Ownership, (New York: Oxford University Press).

WRIGHT, V. (1992), "Public Administration in the Nineties: Trends and Innovations" in Public Administration in the Nineties: Trends and Innovations, Proceedings of XXII International Congress of Administrative Sciences, Vienna: (Bruxelles: International Institute of Administrative Sciences).

YEATMAN, A. (1993). The Reform of Public Management: An Overview, Address to the Royal of Australian Institute of Public Administration, November 1993.

ZIFCAK, S. (1994). New Managerialism: Administrative Reform in Whitehall and Canberra, (Buckingham: Open University Press). 